
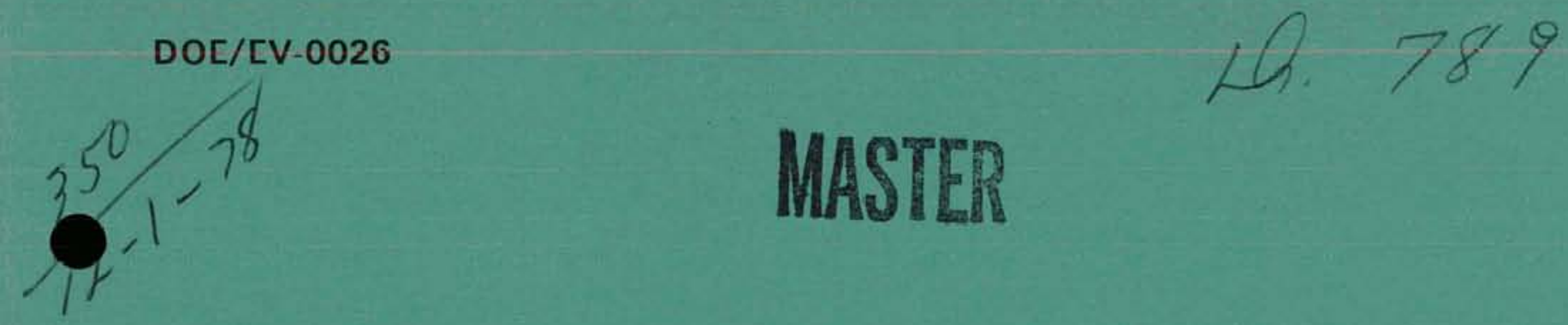

\title{
Roles and Responsibilities of Energy-Related Environmental Organizations
}

September 1978

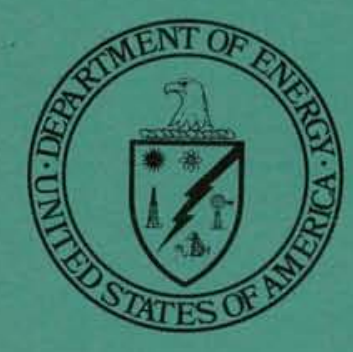

U.S. Department of Energy

Assistant Secretary for Environment Office of Planning Coordination 


\section{DISCLAIMER}

This report was prepared as an account of work sponsored by an agency of the United States Government. Neither the United States Government nor any agency Thereof, nor any of their employees, makes any warranty, express or implied, or assumes any legal liability or responsibility for the accuracy, completeness, or usefulness of any information, apparatus, product, or process disclosed, or represents that its use would not infringe privately owned rights. Reference herein to any specific commercial product, process, or service by trade name, trademark, manufacturer, or otherwise does not necessarily constitute or imply its endorsement, recommendation, or favoring by the United States Government or any agency thereof. The views and opinions of authors expressed herein do not necessarily state or reflect those of the United States Government or any agency thereof. 


\section{DISCLAIMER}

Portions of this document may be illegible in electronic image products. Images are produced from the best available original document. 
DOE/EV-0026

Distribution Categories: UC-2, 13

Roles and Responsibilities

of Energy-Related

Environmental Organizations

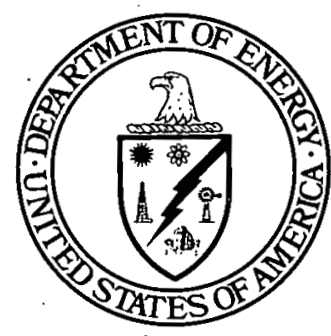

\section{U.S. Department of Energy} Assistant Secretary for Environment Office of Planning Coordination

Washington, D.C. $20545{ }_{95^{10^{13^{8}}}}$

This seport was prepared as an account of work This report was prepared by the United States Government. Neither the United States nor the United States Department of Ener Energs, hor any of their employecs, nor any of the contractors, subcontraciors, or their employes, any warranty, express or impled, or ass es any lega liability or responsibihy for the arescy.conple or usefulness of any linforman, apparalus, product or process disclosed, or represents that its use would not infringe privately owned ights. 
Avallable from:

National Technical Information Service (NTIS)

U.S. Department of Commerce

5285 Port Royal Road

Springfield, Virginia 22161

Price:

Printed Copy:

$\$ 6.50$

Microfiche:

$\$ 3.00$

For sale by the Superintendent of Documents, U.S. Government Printing Office Washington, D.C. 20402

Stock Number 061-000-00170-1 
FOREWORD

Federal energy policy recognizes that environmental quality is a. national priority which must not be sacrificed in the quest for increased domestic energy production.

Within the Department of Energy (DOE), the Office of Environment (EV) is responsible for meeting the nation's energy needs in ways which impose the lowest possible adverse impacts on the environment and on human health and safety. EV monitors all DOE programs to see that they comply with existing. environmental and safety laws, regulations, and policies. It studies the environmental, health and safety effects of new energy technologies--using the results as a basis for providing energy-environmental policy guidance to DOE offices and field organizations.

To be effective, and to avoid duplication of effort, EV needs to communicate with other members of the energy/environmental community. To facilitate such communication, this directory has been assembled of the energy/environmental research, regulatory, and adjudicatory community, describing organizations and their functions. 
THIS PAGE

\section{WAS INTENTIONALLY LEFT BLANK}


TABLE OF CONTENTS

\begin{tabular}{|c|c|c|c|}
\hline & & & Page \\
\hline LIST OF & EXHIBITS & & viii \\
\hline SECTION & $\mathrm{I}$ & INTRODUCTION & 1 \\
\hline & & Perspective & 3 \\
\hline & & Research and Development & 6 \\
\hline & & $\begin{array}{l}\text { Standards Development, Promulgation and } \\
\text { Enforcement }\end{array}$ & 6 \\
\hline & & $\begin{array}{l}\text { The National Environmental Policy Act of } \\
1969\end{array}$ & 10 \\
\hline SECTION & II & DEPARTMENT OF ENERGY, OFFICE OF ENVIRONMENT & 15 \\
\hline SECTION & III & FEDERAL LEGISLATIVE BODIES & 21 \\
\hline & & United States Congress & 21 \\
\hline & & Environmental Study Conference & 22 \\
\hline & & Office of Technology Assessment & 22 \\
\hline & & General Accounting office & 23 \\
\hline & & Congressional Research Service & 24 \\
\hline SECTION & IV & $\begin{array}{l}\text { FEDERAL EXECUTIVE AND OTHER FEDERAL } \\
\text { ORGANIZATIONS }\end{array}$ & 25 \\
\hline & & $\begin{array}{l}\text { Council on Environmental Quality, } \\
\text { Executive Office of the President }\end{array}$ & 25 \\
\hline & & $\begin{array}{l}\text { Office of Management and Budget, } \\
\text { Executive Office of the President }\end{array}$ & 29 \\
\hline & & $\begin{array}{l}\text { Office of Science and Technology Policy, } \\
\text { Executive Office of the President }\end{array}$ & 29 \\
\hline & & Department of Agriculture & 29 \\
\hline & & Department of Commerce & 31 \\
\hline & & Department of Defense & 32 \\
\hline & & Department of Energy & 33 \\
\hline & & $\begin{array}{l}\text { Department of Health, Education and } \\
\text { Welfare }\end{array}$ & 35 \\
\hline
\end{tabular}


TABLE OF CONTENTS (Continued)

$\underline{\text { Page }}$

SECTION IV

(Continued)

$\begin{array}{ll}\text { Department of Housing and Urban } & 37 \\ \text { Development } & 37 \\ \text { Department of Interior } & 39 \\ \text { Department of Labor } & 39 \\ \text { Department of State } & 40 \\ \text { Department of Transportation } & 41 \\ \text { Environmental Protection Agency } & 43 \\ \text { Federal Maritime Commission } & 43 \\ \text { Interstate Commerce Commission } & 44 \\ \text { National Aeronautics and Space } & 44 \\ \text { Administration } & 44 \\ \text { National Science Foundation } & \end{array}$

Occupational Safety and Health Review

Commission

Tennessee Valley Authority 45

Water Resources Council 45

$\begin{array}{lll}\text { SECTION V QUASI-OFFICIAL AGENCIES } & 47\end{array}$

National Academy of Sciences $\quad 47$

National Academy of Engineering . 48

National Research Council 48

Institute of Medicine $\quad 49$

$\begin{array}{ll}\text { Smithsonian Institution } & 49\end{array}$

$\begin{array}{lll}\text { SECTION VI THE JUDICIARY } & 51\end{array}$

SECTION VII STATE AND LOCAL ORGANIZATIONS 55

State Agencies $\quad 57$

Local Agencies $\quad 57$ 
TABLE OF CONTENTS (Concluded)

$\begin{array}{llc} & & \text { Page } \\ \text { SECTION VIII } & \text { REGIONAL AND INTERSTATE ORGANIZATIONS } & 61 \\ & \text { Water Management } & 61 \\ & \text { General Economic Development and } & 65 \\ \text { Resource Management } & 67 \\ & \text { ASSOCIATIONS AND INTEREST GROUPS } & 67 \\ \text { SECTION IX } & \text { Membership Characteristics } & 71 \\ & \text { Organizational Functions } & 74 \\ & \text { Tax Status } & 77 \\ & \text { INTERNATIONAL ORGANIZATIONS } & 77 \\ \text { SECTION XI } & \text { Onited Nations Agencies and Programs } & 80 \\ \text { READING LIST } & \text { CONCLUSION Intergovernmental Organizations } & 81 \\ & & 85\end{array}$


1 Organizational Energy/Environmental Functions

2 Comparison of Energy-Related Environmental Research Expenditures to Other Relevant U.S. Statistics

3 Federal Energy/Environmental Research Funding for FY 1977

4 Major Federal Energy/Environmental Standards and Regulations (As of January 1, 1978)

5 FY 1979 DOE and Office of Environment Budgets and Relationships

6 Allocation of Operating Funds of Office of Environment to Major Budget Items

7 Allocation of FY 1979 Operating Funds of Office of Environment to Performing Institutions

$8 \quad$ Federal Executive Organizations

Energy/Environmental Functions

9 State Organizations

Energy/Environmental Functions 58

10 Regional and Interstate Organizations

Energy/Environmental Functions

11 Functions of Selected Associations and Interest Groups

12 United Nations Organizations

Energy/Environmental Functions

13 Selected Intergovernmental Organizations

Energy/Environmental Functions

14 Selected International Nongovernmental Organizations Energy/Environmental Functions

15 Federal Executive/Other Organizations Interactions and Coordination 


\section{SECTION I}

INTRODUCTION

The simultaneous demands for increasing supplies of energy and enhanced environmental quality resolve themselves into a number of complex issues. Thousands of organizations devote enormous amounts of financial, human, and institutional resources in trying to fulfill both needs. This document is intended to cover only those organizations which are primarily concerned with developing energy technologies and protecting the environment.* According to their major roles, these organizations have been classified as follows: Federal legislative bodies, Federal executive and other Federal organizations, quasi-official agencies, the judiciary, state and local organizations, regional and interstate organizations, associations and interest groups, and international organizations.

As illustrated in Exhibit 1, the objectives and energy/environmental responsibilities of these organizations are subsumed under the following functional areas: research and development (R\&D)/assessment, standards development/promulgation, standards interpretation/ enforcement, standards compliance monitoring/data collection, information storage/dissemination, and public awareness/education.

*The term "environment" is used to encompass public and occupational health and safety and socioeconomic, ecological, legal, cultural, and esthetic concerns. For convenience, these are referred to as environmental, health, and safety (EH\&S) issues. 


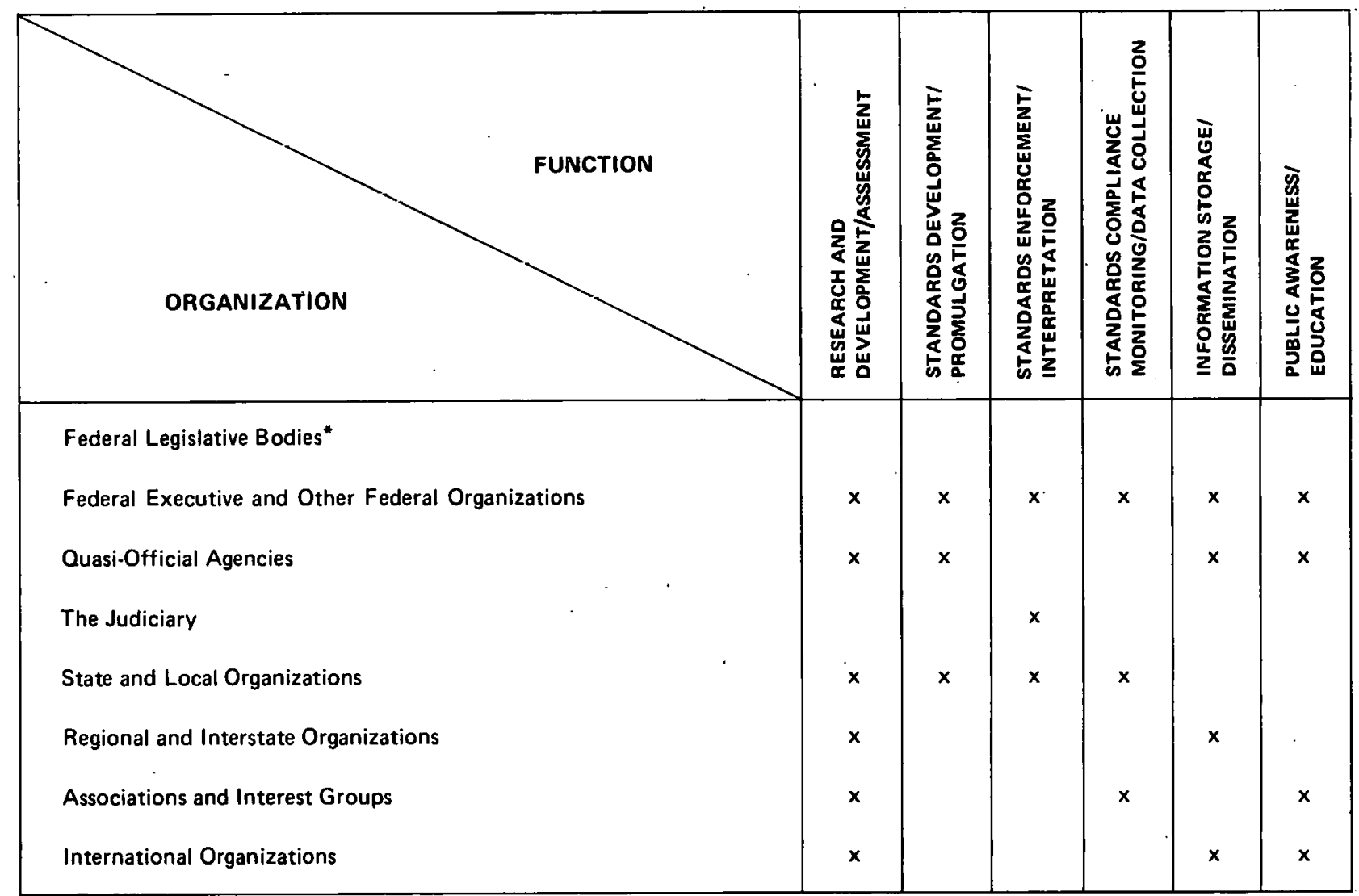

* Have primarily oversight functions.

EXHIBIT 1

ORGANIZATIONAL ENERGY/ENVIRONMENTAL FUNCTIONS

2 
Particular emphasis is placed on $R \& D$ and standards development, promulgation and enforcement. The interrelationships and program coordination among various organizations are described separately. A list of readings is included, for those interested in pursuing these subject.s in greater depth.

\section{PERSPECTIVE}

While a full discussion of all the organizations concerned with energy-related environmental, health, and safety (EH\&S) issues is beyond the scope of this document, it is possible to indicate here the magnitude of the activities involved. Funding levels offer one obvious measure.

In attempting to quantify the total Federal energy-related environmental effort, it is often difficult to separate from an agency's overall budget that portion devoted to energy-related environmental activities. Fortunately, data on Federal support for energy/environmental research is available from the Department of Energy's Inventory of Federal Energy-Related Environmental Research, * indicating that funding for this research increased from $\$ 286.8 \mathrm{mil}-$ lion in FY 1975 to $\$ 580.1$ million in FY 1977. Despite this increase, energy-related environmental research expenditures remain a very

\footnotetext{
*A report on energy-related environmental and safety research in the Federal sector. Prepared annually by DOE, as required by the Energy Reorganization Act of 1974 (PL 93-438) and the Federal Non-Nuclear Research and Development Act of 1974 (PL 93-577). Also known as the Federal Inventory.
} 
small percentage of national energy expenditures, as shown in Exhibit 2. In fact, U.S. personal consumption energy expenditures in 1977 comprised only 5 percent of the U.S. Gross National Product. Budget profiles of the two executive agencies most involved in energy/environmental research, the Environmental Protection Agency (EPA) and the Department of Energy (DOE), illustrate Federal funding in this area very well. EPA's FY 1978 budget allocated more than $\$ 260$ million for research and development, about $\$ 400$ million for abatement and control, and about $\$ 70$ million for enforcement activities. Only a portion of these funds went to energy-related programs. Of DOE's $\$ 12.6$ billion FY 1978 budget, $\$ 285$ million was allocated to the Office of Environment for energy-related environmental programs. The thousands of non-Federal energy/environmental organizations have widely varying budgets. For example, the World Health Organization of the United Natinns has an annual budget of about \$137 million, of which only a part is energy-related. On a smaller scale, the governor of Virginia has allocated $\$ 2.2$ million for the state Energy Office, and $\$ 282,700$ for the Council on the Environment in that state's FY 1978-79 (two-year) budget.

Expenditures by associations and interest groups also vary widely. The Environmental Defense Fund, Inc., conducts research and/ or initiates litigation with an annual budget of about $\$ 1.3$ million: A much larger program is carried out by the National Wildlife Federation, which annually spends $\$ 20$ million on environmental 


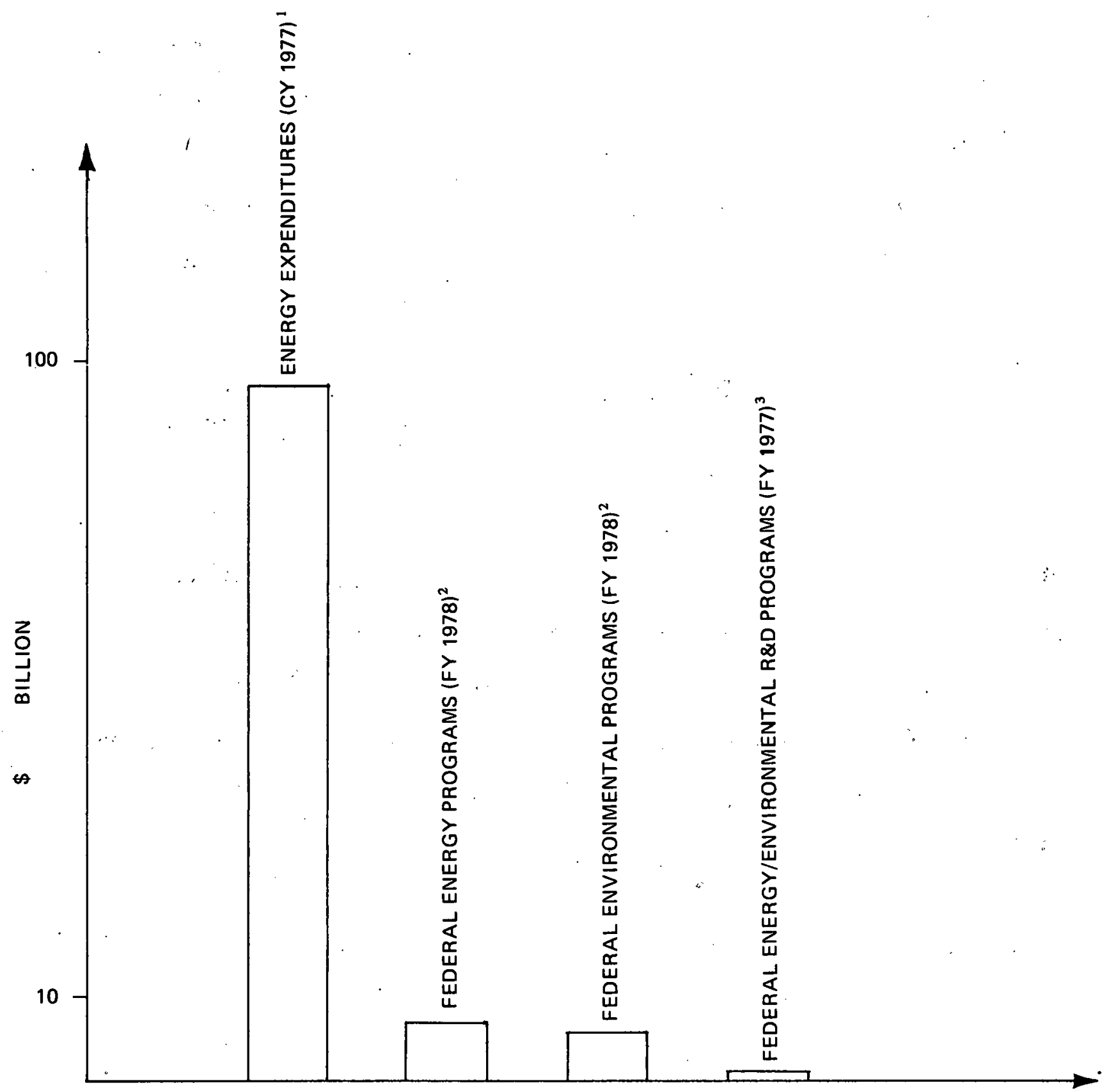

U.S. ENERGY/ENVIRONMENT STATISTICS

${ }^{1}$ Source:! U.S. personal consumption energy expenditures from the Survey of Current Business, Department of Commerce, Bureau of Economic Analysis, Jan. 1978.

${ }^{2}$ Source: Office of Managemient and Budget, Executive Office of the President, The Budget of the United States Government, 1978.

${ }^{3}$ Source: Department of Energy, Inventory of Federal Energy-Re/ated Environment and Safety Research (in press).

EXHIBIT 2

COMPARISON OF ENERGY-RELATED ENVIRONMENTAL RESEARCH EXPENDITURES TO OTHER RELEVANT U.S. STATISTICS 
issues, including energy conservation and the development of environmentally attractive alternative energy sources. Trade and/or industry organizations, such as the American Petroleum Institute and the American Gas Association, have annual budgets of $\$ 24.6$ and $\$ 30$ million, respectively.

RESEARCH AND DEVELOPMENT

Federal energy-related EH\&S research can be grouped: into three categories:* Biomedical and Environmental Research, Environmental Control Technology Research, and Operational Safety Research. The number of programs and funding levels for each Federal agency included in the FY 1977 DOE Federal Inventory are shown in Exhibit 3, providing some indication of the magnitude of Federa1 R\&D efforts in this area.

State and local agency $R \& D$ is conducted in support of regulatory functions. Regional agencies, international organizations, and associations and interest groups either sponsor or perform $R \& D$ as necessary to sustain their objectives.

STANDARDS DEVELOPMENT, PROMULGATION AND ENFORCEMENT

Agencies at all levels of government possess regulatory authority over materials, activities, industries and organizations as granted by executive or legislative mandate. This authority is exercised by developing and/or enforcing standards, granting permits

*These categories are used in the Department of Energy's Inventory of Federal Energy-Related Environmental and Safety Research. 


\begin{tabular}{|c|c|c|}
\hline AGENCY & $\begin{array}{c}\text { NUMBER OF } \\
\text { PROJECTS REPORTED }\end{array}$ & $\begin{array}{l}\text { REPORTED FUNDING } \\
\text { (\$ IN MILLIONS) }\end{array}$ \\
\hline Department of Agriculture & 11 & 7.7 \\
\hline Department of Commerce & 112 & 35.0 \\
\hline Department of Defense & 7 & 0.2 \\
\hline \multicolumn{3}{|l|}{ Department of Health, Education } \\
\hline and Welfare & 331 & 33.4 \\
\hline Department of the Interior & 68 & 14.7 \\
\hline Department of Transportation & 38 & 4.5 \\
\hline Environmental Protection Agency & 1013 & 90.9 \\
\hline Energy Research and Development & . & \\
\hline Administration * & 1474 & 287.5 \\
\hline Federal Energy Administration* & 6 & 0.2 \\
\hline National Science Foundation & 72 & 4.7 \\
\hline Nuclear Regulatory Commission & 101 & 91.6 \\
\hline Tennessee Valley Authority & 63 & 9.7 \\
\hline TOTAL & 3296 & 580.1 \\
\hline
\end{tabular}

- Now Department of Energy

Source: Department of Energy, Invẹtory of Fedëral Energy-Related Environment and Safety Research (In press) 
or rights, and other associated activities. The major Federal EH\&S regulations which may directly affect energy development are shown in Exhibitt 4.

Among those Federal agencies whose regulatory responsịilities are most directly related to the EH\&S effects of energy resource and technology development are the Environmental Protection Agency (EPA), the Occupational Safety and Health Administration (OSHA), the Mine Safety and Health Administration, the Nuclear Regulatory Commission (NRC), and the Office of Surface Mining (OSM). . A second group of Federal agencies with energy/environmental regulatory authority is composed of: the Army Corps of Engineers (COE), the Bureau of Land Management (BLM), the Bureau of Reclamation, the U.S. Geological Survey (USGS), the Food and Drug Administration, the Interstate Commerce Commission, the Materials Transportation Bureau, and the U.S. Coast Guard (USCG). Taken together, these agencies regulate energy-related impacts on air and water quality, land and water use, hazardous substances release, radiation control, noise pollution, and occupational health and safety.

State and local governments also possess regulatory authority, often delegated from the Federal government. This authority includes the power to promulgate and enforce air and water quality standards, which are frequently more stringent than those set by the Environmental Protection Agency. State enforcement functions include the 


\begin{tabular}{|c|c|c|c|c|c|}
\hline & NAME & OBJECTIVE & SCOPE & LEGISLATION & AGENCIES \\
\hline \multirow{7}{*}{ 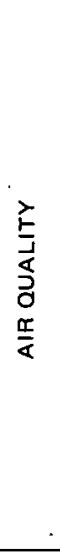 } & $\begin{array}{l}\text { National Ambient Air } \\
\text { Quality Standards }\end{array}$ & $\begin{array}{l}\text { Improve and control ambient } \\
\text { air quality }\end{array}$ & $\begin{array}{l}\text { TSP, } \mathrm{SO}_{\mathbf{X}}, \mathrm{NO}_{\mathbf{X}}, \\
\mathrm{CO}, \mathrm{HC}\end{array}$ & $\begin{array}{l}\text { Clean Air Act }(1977)^{\circ} \\
\text { (CAA) }\end{array}$ & $\begin{array}{l}\text { Promulgation, monitoring, } \\
\text { enforcement: EPA }\end{array}$ \\
\hline & $\begin{array}{l}\text { Standards of Performance } \\
\text { for New Stationary } \\
\text { Sources }\end{array}$ & $\begin{array}{l}\text { Control emissions from new } \\
\text { and modified stationary } \\
\text { sources }\end{array}$ & $\begin{array}{l}\text { Pollutants from new or } \\
\text { modified stationary } \\
\text { sources }\end{array}$ & CAA & $\begin{array}{l}\text { Promulgation, monitoring, } \\
\text { enforcement: EPA }\end{array}$ \\
\hline & $\begin{array}{l}\text { National Emission Standards } \\
\text { for Hazardous Air } \\
\text { Pollutants }\end{array}$ & $\begin{array}{l}\text { Control emissions of highly } \\
\text { toxic pollutants }\end{array}$ & Highly toxic pollutants & CAA & $\begin{array}{l}\text { Promulgation, monitoring, } \\
\text { enforcement: EPA }\end{array}$ \\
\hline & $\begin{array}{l}\text { Automobile Emission } \\
\text { Standards }\end{array}$ & $\begin{array}{l}\text { Control emissions from } \\
\text { automobiles }\end{array}$ & $\begin{array}{l}\mathrm{CO}, \mathrm{NO}_{\mathrm{X}}, \mathrm{HC} \text {, from } \\
\text { automobiles }\end{array}$ & $\begin{array}{l}\text { CAA; Energy Supply and En- } \\
\text { vironmental Coordination } \\
\text { Act (ESECA) of } 1974(1975)\end{array}$ & $\begin{array}{l}\text { Promulgation, monitoring, } \\
\text { enforcement: EPA }\end{array}$ \\
\hline & Aircraft Emission Standards & $\begin{array}{l}\text { Control emissions from } \\
\text { aircraft }\end{array}$ & $\begin{array}{l}\text { Pollutants from aircraft } \\
\text { engines }\end{array}$ & CAA & $\begin{array}{l}\text { Promulgation, monitoring, } \\
\text { enforcement: EPA }\end{array}$ \\
\hline & $\begin{array}{l}\text { Federal Activities Perform- } \\
\text { ance Standards }\end{array}$ & $\begin{array}{l}\text { Control emissions by Federal } \\
\text { installations }\end{array}$ & $\begin{array}{l}\text { Pollutants from Federal } \\
\text { installations }\end{array}$ & CAA & $\begin{array}{l}\text { Promulgation, monitoring, } \\
\text { enforcement: EPA }\end{array}$ \\
\hline & $\begin{array}{l}\text { Regulations on Energy- } \\
\text { Related Authority }\end{array}$ & $\begin{array}{l}\text { Control emissions from } \\
\text { power plants converting } \\
\text { to coal }\end{array}$ & $\begin{array}{l}\text { Pollutants for which ambient } \\
\text { standards were not } \\
\text { promulgated }\end{array}$ & ESECA of 1974 & $\begin{array}{l}\text { Promulgation, monitoring, } \\
\text { enforcement: EPA }\end{array}$ \\
\hline \multirow{6}{*}{ 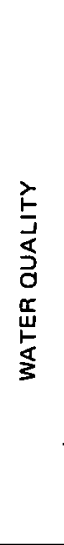 } & Water Quality Standards & $\begin{array}{l}\text { Maintain adequate water } \\
\text { quality for various uses }\end{array}$ & $\begin{array}{l}\text { All known harmful } \\
\text { pollutants }\end{array}$ & $\begin{array}{l}\text { Clean Water Act (CWA) of } \\
\text { 1977; Safe Drinking } \\
\text { Water Act }(1977)\end{array}$ & $\begin{array}{l}\text { Promulgation: EPA; moni- } \\
\text { toring; enforcement: } \\
\text { states or EPA }\end{array}$ \\
\hline & $\begin{array}{l}\text { National Pollutant Dis- } \\
\text { charge Elimination } \\
\text { System** }\end{array}$ & $\begin{array}{l}\text { Control discharge of pollu- } \\
\text { tants into waterways }\end{array}$ & All point sources & CWA of 1977 & $\begin{array}{l}\text { Promulgation: EPA; moni- } \\
\text { toring; enforcement: } \\
\text { states or EPA }\end{array}$ \\
\hline & Pretreatment Standards & $\begin{array}{l}\text { Control toxic substances } \\
\text { discharged to municipal } \\
\text {-treatment works }\end{array}$ & $\begin{array}{l}\text { All industrial discharges } \\
\text { of toxic substances }\end{array}$ & CWA of 1977 & $\begin{array}{l}\text { Promulgation: EPA; moni- } \\
\text { toring, enforcement: } \\
\text { states or EPA }\end{array}$ \\
\hline & $\begin{array}{l}\text { Thermal Discharge } \\
\text { Standards }\end{array}$ & $\begin{array}{l}\text { Control impact of heat on } \\
\text { water quality }\end{array}$ & $\begin{array}{l}\text { Cooling discharges to } \\
\text { surface waters }\end{array}$ & CWA of 1977 & $\begin{array}{l}\text { Promulgation: EPA; moni- } \\
\text { | toring; enforcement: } \\
\text { states or EPA }\end{array}$ \\
\hline & Ocean Dumping Regulations & $\begin{array}{l}\text { Control dumping of radio- } \\
\text { active wastes into the } \\
\text { marine environment }\end{array}$ & $\begin{array}{l}\text { Disposition of wastes by } \\
\text { ocean dumping }\end{array}$ & $\begin{array}{l}\text { Marine Protection, Research, } \\
\text { and Sanctuaries Act of } \\
1972(1976)\end{array}$ & $\begin{array}{l}\text { Promulgation, monitoring, } \\
\text { enforcement: EPA; } \\
\text { surveillance: USCG, COE }\end{array}$ \\
\hline & $\begin{array}{l}\text { Outer Continental Shelf } \\
\text { (OCS) Environmental } \\
\text { Regulations }\end{array}$ & $\begin{array}{l}\text { Control oil discharges from } \\
\text { oil and gas operations }\end{array}$ & $\begin{array}{l}\text { OCS oil and gas operations } \\
\text { and leasing }\end{array}$ & $\begin{array}{l}\text { Outer Continental Shelf } \\
\text { Lands Act (1953) }\end{array}$ & $\begin{array}{l}\text { Promulgation, monitoring, } \\
\text { enforcement: BLM, USGS }\end{array}$ \\
\hline 总崫 & $\begin{array}{l}\text { Surface Mining Regulations } \\
\text { (interim) }\end{array}$ & $\begin{array}{l}\text { Restore quality of mined } \\
\text { land }\end{array}$ & $\begin{array}{l}\text { Surface mines and surface } \\
\text { effects of deep mines }\end{array}$ & \begin{tabular}{|c|} 
Surface Mining Control and \\
Reclamation Act of 1977
\end{tabular} & \begin{tabular}{|l} 
Promulgation, monitoring, \\
enforcement: OSM
\end{tabular} \\
\hline \multirow{3}{*}{ 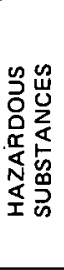 } & Pesticide Standärds & $\begin{array}{l}\text { Control environmental } \\
\text { release of pesticides } \\
\end{array}$ & $\begin{array}{l}\text { Manufacturing, distribution } \\
\text { and use operations }\end{array}$ & $\begin{array}{l}\text { Federal Environmental Pesti- } \\
\text { cide Control Act of } 1972 \\
(1975)\end{array}$ & $\begin{array}{l}\text { Promulgation: EPA; moni- } \\
\text { toring, enforcement: } \\
\text { states, EPA }\end{array}$ \\
\hline & $\begin{array}{l}\text { Hazardous Waste Standards } \\
\text { (pending) }\end{array}$ & $\begin{array}{l}\text { Control release of hazardous } \\
\text { wastes }\end{array}$ & $\begin{array}{l}\text { Generation, transport, treat- } \\
\text { ment, storage, or disposal } \\
\text { operations }\end{array}$ & $\begin{array}{l}\text { Resource Conservation and } \\
\text { Recovery Act of } 1976\end{array}$ & $\begin{array}{l}\text { Promulgation: EPA; moni- } \\
\text { toring, enforcement: } \\
\text { states, EPA }\end{array}$ \\
\hline & $\begin{array}{l}\text { Toxic Substances Standards } \\
\text { (pending) }\end{array}$ & $\begin{array}{l}\text { Control dissemination of } \\
\text { hazardous substances }\end{array}$ & $\begin{array}{l}\text { Manufacturing, distribution, } \\
\text { use, and disposal operations }\end{array}$ & $\begin{array}{l}\text { Toxic Substances Control } \\
\text { Act }(1976)\end{array}$ & $\begin{array}{l}\text { Promulgation: EPA; moni- } \\
\text { toring, enforcement: } \\
\text { states, EPA }\end{array}$ \\
\hline 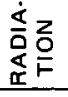 & $\begin{array}{l}\text { Radiation Protection } \\
\text { Standards }\end{array}$ & $\begin{array}{l}\text { Control radiation from } \\
\text { nuclear fuel cycle }\end{array}$ & $\begin{array}{l}\text { Generation, transport, } \\
\text { storage, or disposal } \\
\text { operations } \\
\end{array}$ & $\begin{array}{l}\text { Atomic Energy Act of } 1954 \\
\text { (1977): Energy Reorganiza- } \\
\text { tion Act of } 1974(1977)\end{array}$ & \begin{tabular}{|l} 
Promulgation: EPA, NRC; \\
monitoring, enforcement: \\
various agencies
\end{tabular} \\
\hline \multirow{5}{*}{$\begin{array}{l}\text { W } \\
\frac{\mathrm{O}}{2} \\
2\end{array}$} & Noise Emission Standards & $\begin{array}{l}\text { Control ambient noise } \\
\text { levels }\end{array}$ & $\begin{array}{l}\text { Transportation, construc- } \\
\text { tion, and other noisy } \\
\text { products }\end{array}$ & $\begin{array}{l}\text { Noise Control Act (NCA) of } \\
1972(1976)\end{array}$ & $\begin{array}{l}\text { Promulgation, monitoring, } \\
\text { enforcement: EPA }\end{array}$ \\
\hline & $\begin{array}{l}\text { Aircraft and Airport } \\
\text { Noise Standards }\end{array}$ & Control aircraft noise & All aircraft & $\begin{array}{l}\text { Federal Aviation Act } \\
\text { of } 1958(1968) ; \\
\text { NCA of } 1972\end{array}$ & $\begin{array}{l}\text { Promulgation, monitoring, } \\
\text { enforcement: FAA } \cdots\end{array}$ \\
\hline & Railroad Noise Standards & Control railroad noise & Trains & NCA of 1972 & $\begin{array}{l}\text { Promulgation: EPA; moni- } \\
\text { toring, enforcement: DOT*** }\end{array}$ \\
\hline & $\begin{array}{l}\text { Interstate Motor Carrier } \\
\text { Noise Standards }\end{array}$ & Control truck noise. & $\begin{array}{l}\text { Trucks over } 10,000 \text { lbs used } \\
\text { in interstate commerce }\end{array}$ & NCA of 1972 & $\begin{array}{l}\text { Promulgation: EPA: moni- } \\
\text { toring, enforcement: DOT*** }\end{array}$ \\
\hline & $\begin{array}{l}\text { Occupational Exposure } \\
\text { Standards }\end{array}$ & $\begin{array}{c}\text { Control occupational } \\
\text { noise exposure }\end{array}$ & \begin{tabular}{|c|} 
Noisy occupational \\
environments
\end{tabular} & $\begin{array}{l}\text { Occupational Safety and } \\
\text { Health Act of } 1970\end{array}$ & $\begin{array}{l}\text { Promulgation, monitoring, } \\
\text { enforcement: OSHA }\end{array}$ \\
\hline$\frac{u}{4}$ & $\begin{array}{l}\text { Occupational Health } \\
\text { and Safety Standards }\end{array}$ & $\begin{array}{l}\text { Protect health and safety } \\
\text { of workers }\end{array}$ & Occupational exposure & $\begin{array}{l}\text { Occupational Safety and } \\
\text { Health Act of } 1970\end{array}$ & $\begin{array}{l}\text { Promulgation, monitoring, } \\
\text { enforcement: OSHA }\end{array}$ \\
\hline
\end{tabular}

- Parentheses show date of passage or most recent amendment.

* Encompasses industrial and municipal effluent limitations for 1977 and 1983, national standards of performance for new sources, and toxic effluent standards.

*** Noise standards enforcement functions of the Federal Aviation Administration (FAA) and the Department of Transportation (DOT) are not separately addressed in the text. 
issuance of permits for construction of facilities and discharge of

pollutants. Local governments may also enforce zoning ordinances and may regulate such activities as open burning, waste disposal, water use, and construction.

While the actual development and enforcement of regulations is carried out by government agencies, quasi-official organizations and private sector organizations may influence the process in several ways. For example, private organizations often develop standards, under contract to government regulatory agencies. Moreover, the private sector often exercises its First Amendment rights by lobbying to: affect the substance of new legislation, or by litigating to influence the interpretation of laws, regulations, or standards.

THE NATIONAL ENVIRONMENTAL POLICY ACT OF 1969

The National Environmental Policy Act of 1969 (NEPA) became law on January 1, 1970. The Act was passed against a background of significant environmental deterioration--including loss of valuable open spaces, critical air and water pollution problems, needless deforestation, rising noise levels, and the growing use of pesticides and chemicals--without adequate consideration of the consequences.* Congress felt that existing governmental mechanisms were ill-equipped to face these problems for two reasons. First, Federal agencies lacked the expertise and commitment to identify and resolve the

*U.S. Senate Committee on Interior and Insular Affairs, Report on National Environmental Policy Act of 1969 (Senate Report No. 296, 1969). 
environimental consequences of their actions. Traditional policies were primarily designed to enhance the production of goods and increase the Gross National Product. Declining environmental quality was seen as the price paid for the nation's unrivaled technological abilities. Second, even where agencies were aware that their actions could adversely affect environmental values, they often lacked the authority to take remedial action.

'In passing NEPA, Congress had three major purposes in mind: It wanted first to enlarge the Federal agencies' basic mandates through enactment of a national environmental policy. A second purpose was to establish specific action-forcing mechanisms to implement the policy. Finally, Congress wanted to create a Council on Environmental Quality to monitor agency implementation and to advise the President on environmental matters.

National environmental policy is set forth in section 101 (b) of the Act. Agencies are to use all practicable means, consistent with other considerations of national policy, to:

(1) fulfill the responsibilities of each generation as trustee of the environment for succeeding generations;

(2) assure for all Americans safe, healthful, productive, and esthetically and culturally pleasing surroundings;

(3) attain the widest range of beneficial uses of the environment without degradation, risk to health or safety, or other undesirable and unintended consequences;

(4) preserve important historic, cultural, and natural aspects of our national heritage, and maintain, wherever possible, an environment which supports diversity and variety" of individual choice; 
(5) achieve a balance between population and resource use which will permit high standards of living and a wide sharing of life's amenities; and

(6) enhance the quality of renewable resources and approach the maximum attainable recycling of depletable resources.

NEPA's action-forcing mechanism is contained in section 102 . To the fullest extent possible, agencies are directed to utilize a systematic, interdisciplinary approach to insure integration of environmental factors in the decisionmaking process. Agencies are also directed to study and develop alternatives to Federal proposals. Another key feature of section 102 is the requirement that agencies prepare detailed environmental impact statements for "major Federal actions significantly affecting the quality of the human environment."

The Council on Environmental Quality (CEQ) has established guidelines for the implementation of NEPA. While these guidelines (established August 1, 1973) do. not have the force of 1aw, Federal courts give them great weight in determining whether an agency has complied with the procedural requirements of the Act. In addition, the $\mathrm{CEQ}$ recently issued proposed regulations* in response to Executive Order 11991 which, unlike the guidelines, will be binding on Federal agencies.

Each Federal agency must also develop systematic regulations for implementing the Act. Common aspects of these regulations are discernible. An agency must determine whether a particular action under \%43 FR 25230 (June 9, 1978) 
consideration may have a significant environmental impact, thereby requiring a detailed environmental impact statement (EIS). Three general options are available regarding this determination. First, a summary negative declaration may be issued when it is obvious from the nature of the action that its environmental consequences will be minor.

Second, an environmental assessment may be prepared which provides a record upon which a decision may be based as to whether or not to prepare an EIS. The assessment identifies areas of environmental concern, addresses appropriate alternatives, presents a convincing case for environmental non-significance, and insures that the agency takes a hard look at the environmental consequences of its actions. Assessments may be prepared for regulatory or legislative actions, either on an individual or programmatic basis. Third, if impacts are potentially significant within the meaning of NEPA, a detailed EIS must be prepared. The process starts " with a draft EIS which fully explores all relevant impacts and project alternatives. Agencies with interest or expertise in the matter and the public are given an opportunity to comment on the draft statement, normally during a 45-day commenting period. Formal or informal public hearings may be held, depending upon the procedures outlined in the agency's implementing regulations and the requirements of the Administrative Procedure Act. Ali substantive comments of an 
environmental nature must be responded to and attached to a final EIS prepared by the agency.

Impact statements and assessments must be considered by Federal agencies in deciding whether or not to proceed with proposed activities. This typically involves a balancing of environmental impacts with other considerations of national policy. The balancing function is not normally incorporated into environmental documents. Based upon NEPA's implicit authority, agencies may, at their discretion, grant or deny proposed projects, or may impose mitigating measures to alleviate the adverse impacts identified in assessments and statements.

Most Federal agencies have a staff office responsible for overseeing compliance with NEPA. Compliance includes writing and receiving approval of EIS's for agency projects, assuring EIS implementation for project duration, and reviewing and commenting on applicable EIS's written by other Federal agencies.

Since NEPA is designed to enhance environmental quality and assure public health and safety, it is an important consideration in evaluating environmental responsibilities. .However, since it applies to all Federal programs, not just those which are energy-related, NEPA will not be included in the following pages as a specific responsibility of Federal agencies. 
DEPARTMENT OF ENERGY, OFFICE OF ENVIRONMENT

Most of the organizations described herein emphasize either the development of energy technologies or the protection of the environment. The Office of Environment of the Department of Energy (DOE) does both. DOE, therefore, has a central role in the energy/ environment decisionmaking process.

The DOE Office of Environment (EV) is one of twelve DOE operating organizations. DOE energy missions range from conservation to regulation and commercialization. Elements of $\mathrm{EV}^{\prime} \mathrm{s}$ budget are included in four of the ten DOE mission categories, as depicted in Exhibit 5. The public law establishing the Department mandates eleven functions to be performed by eight Assistant Secretaries. The Assistant Secretary for Environment is charged with:

"Environmental responsibilities and functions, including advising the Secretary with respect to the conformance of the Department's activities to environmental protection laws and principles, and conducting a comprehensive program of research and development on the environmental effects of energy technologies and programs."*

Consistent with its legislative mandate, EV is organized to perform two essential functions. The office insures DOE conformance with environmental goals by:

(1) implementing the National Environmental Policy Act and other environmental legislation, including environmenta1 considerations in DOE decisionmaking, policies, programs, and projects;

ॠ42 USC 7133, section 203(a)(3). 
TOTAL DOE FY 1979 BUDGET: $\$ 12,593$ MILLION
TOTAL FY 1979 BUDGET OF OFFICE OF ENVIRONMENT: $\$ 285$ MILLION

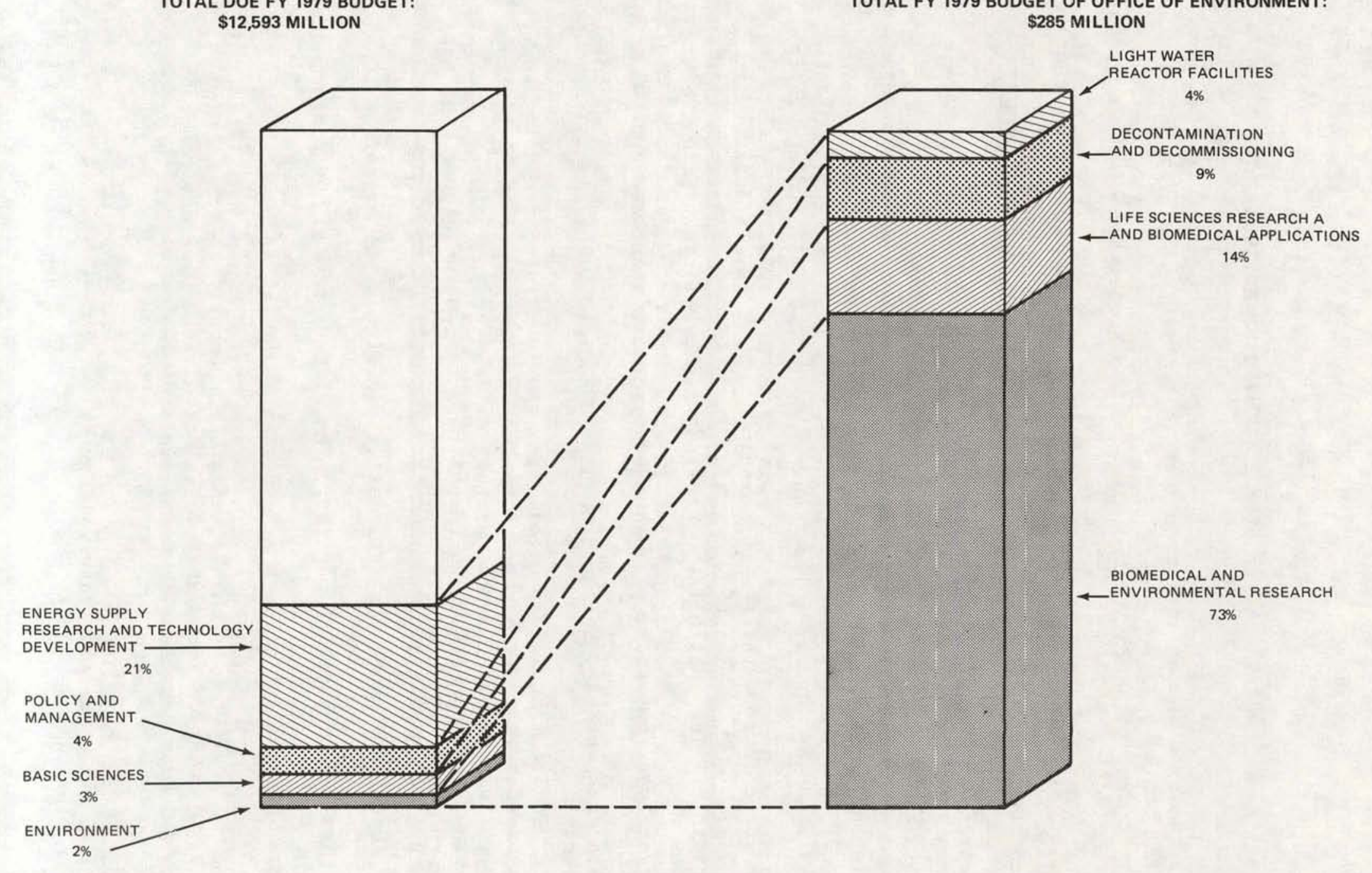

EXHIBIT 5

FY 1979 DOE AND OFFICE OF ENVIRONMENT BUDGETS AND RELATIONSHIPS 
(2) performing energy systems assessments and policy analyses trom the environmental perspective; and

(3) developing safety standards and decontamination/decommissioning policy and procedures for DOE facilities and selected other sites.

EV's second major function is to identify and resolve energyrelated environmental problems. It does this by conducting research and development, evaluating control technology, and evaluating safety devices and processes.

The FY 1979 Presidential Budget for the Office of Environment describes the kinds of activities which it performs. Exhibit 6 summarizes the major items which comprise the $\$ 285$ million budget, most of which goes for contractor-conducted R\&D. Exhibit 7 shows the allocation of FY 1979 funds to performing institutions (i.e., government-owned, contractor-operated facilities [GOCO]; energy research centers [ERC]; universities; industry; and other Federal agencies). Since FY 1977, funding for GOCO's, ERC's and industry has been increasing, while funding for universities and other Federal agencies has been decreasing.

In addition to the above funds, approximately $\$ 11.5$ million is allocated to Federal employees' salaries and related expenses in the EV organization. Furthermore, it should be noted that there are DOE personnel and dollars for environmental programs, including environmental research and development, environmental impact statement preparation and control technology, in offices other than the office of Environment. 


\begin{tabular}{|c|c|}
\hline BUDGET ITEMS & $\begin{array}{c}\text { FY } 1979 \\
\text { (\$ in millions) }\end{array}$ \\
\hline LIGHT WATER REACTOR FACILITIES & 6.5 \\
\hline OVERVIEW AND ASSESSMENT & 48.7 \\
\hline Overview Management & 6.0 \\
\hline Environmental Policy Analysis & 5.4 \\
\hline Integrated Assessment & 10.2 \\
\hline Environmental Engineering & 16.0 \\
\hline Operational and Environmental Safety & 11.0 \\
\hline BIOMEDICAL AND ENVIRONMENTAL RESEARCH & 135.3 \\
\hline Human Health Studies & 20.8 \\
\hline Health Effects Research in Biological Systems & 42.7 \\
\hline Environmental Studies & 49.7 \\
\hline Physical and Technological Studies & 22.1 \\
\hline LIFE SCIENCES RESEARCH AND BIOMEDICAL APPLICATIONS & 39.7 \\
\hline DECONTAMINATION AND DECOMMISSIONING & 25.0 \\
\hline TOTAL OPERATING FUNDS & 255.2 \\
\hline TOTAL CONSTRUCTION AND CAPITAL ACQUISITIONS & 29.4 \\
\hline TOTAL & 284.6 \\
\hline
\end{tabular}

Source: FY 1979 DOE Presidential Budget

EXHIBIT 6 ALLOCATION OF OPERATING FUNDS OF OFFICE OF ENVIRONMENT TO MAJOR BUDGET ITEMS 


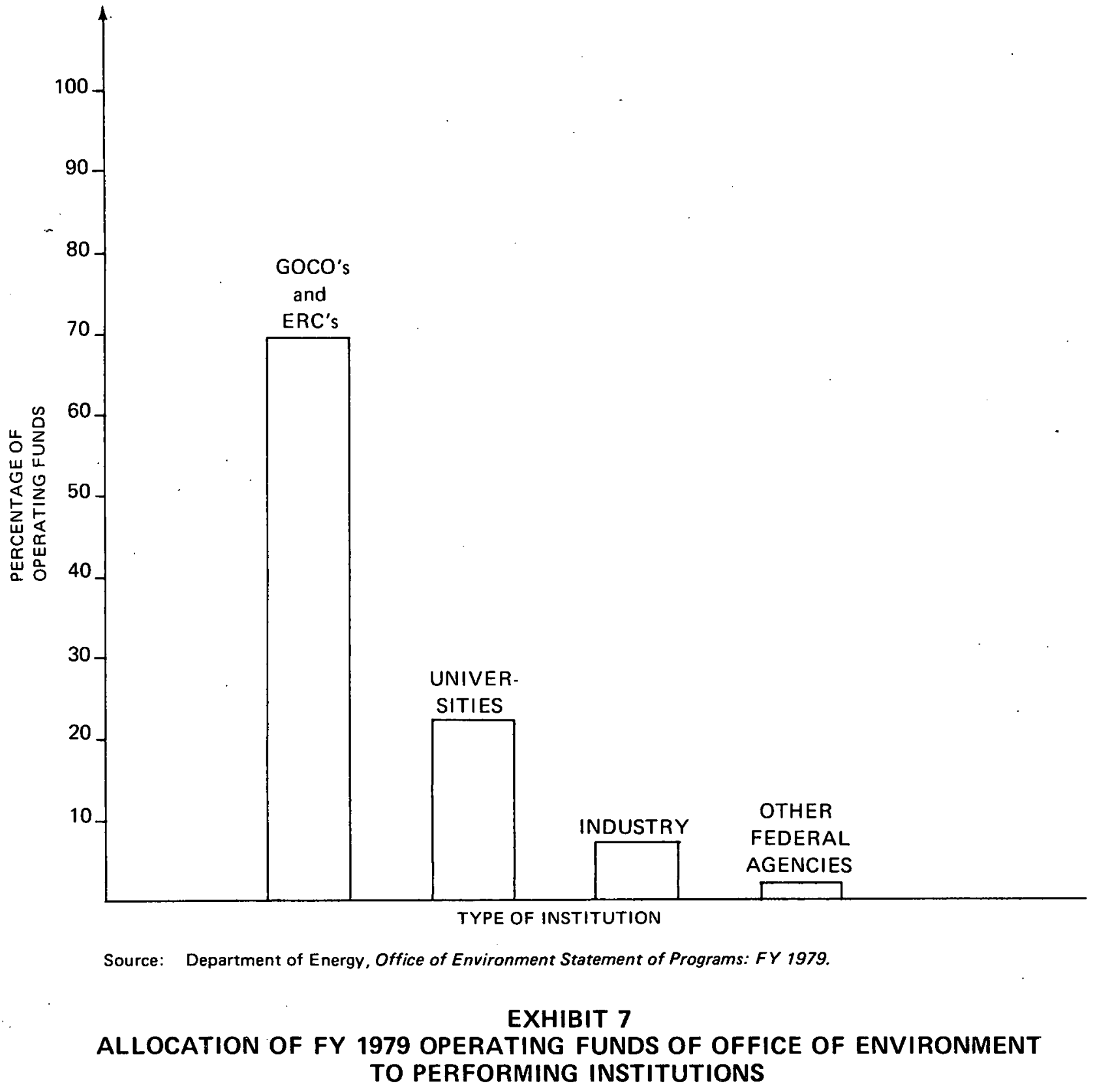


THIS PAGE

\section{WAS INTENTIONALLY \\ LEFT BLANK}



SECTION III

FEDERAL LEGISLATIVE BODIES

UNITED STATES CONGRESS

The Congress of the United States has various responsibilities for environmental, health, and safety (EH\&S) matters, including program authorization, appropriations, and. oversight. In any legislative session, most committees and subcommittees at least touch on energy-related environmental subjects, from either technological, fiscal, conservation, government operations, or other points of view. Authorization subcommittees perform the most continual oversight and evaluation, usually over several Federal executive agencies having similar missions.

The Senate Committee on Energy and Natural Resources participates in a variety of legislative functions and oversight responsibilities, including the authorization of monies for Federal EH\&S programs. Specifically, these activities take place in the Subcommittee on Energy Research and Development.

In the House of Representatives, legislative and oversight responsibilities for research and development are assigned to the. Committee on Science and Technology. The Subcommittee on the Environment and the Atmosphere authorizes funds for environmental programs. Two other House committees, the Committee on Interstate and Foreign Commerce and the Committee on Interior and Insular 
Affairs, have authority over other aspects of energy-related environmental programs. The Senate and House each have a Committee on Appropriations which allocates funds for all Federal energyrelated environmental and other activities. Subcommittees hold hearings and recommend funding levels for consideration by the full Committee and the House.

ENVIRONMENTAL STUDY CONFERENCE

The Environmental Study Conference is a bipartisan group organized in the House of Representatives in 1975 to provide U.S. Representatives with in-depth information about environmental and energy-related issues. The Conference provides weekly analyses of pending energy-related environmental legislation and committee activities. Topics include basic issues, anticipated amendments, and the views of key Representatives, the Administration, and some nonGovernment organizations on environmental matters.

OFFICE OF TECHNOLOGY ASSESSMENT

The Office of Technology Assessment (OTA) began operations in 1974, serving as an advisory arm of the Congress. It provides legislators with independent analyses of and information on the potential impacts of technological applications. OTA assessments address such critical areas as food, health, oceans, materials resources, transportation, technology, and world trade. 
OTA consists of a non-partisan Congressional Board, a Director, a Deputy Director, an Advisory Council, and consultants. The Congressional Board sets the policies of the office and is the sole and exclusive oversight body. The Director is chief executive officer and is responsible solely to the Board. The citizens' Advisory Council and individual consultants advise OTA on technology assessment matters when requested by the Congressional Board.

GENERAL ACCOUNTING OFFICE

The General Accounting Office (GAO) is the investigatory arm of Congress. Its primary function is to aid the Congress in meeting oversight responsibilities.

GAO conducts on-site monitoring of Federal agency energy-related environmental and other activities to insure program implementation in accordance with the original legislative intent of the Congress. GAO is also concerned that programs be executed efficiently and economically. If the on-site monitoring reveals flaws in program or agency administration, a more thorough study is initiated.

Even though about 75 percent of the GAO's workload is selfgenerated by these monitoring activities, any member or committee of Congress may request specific investigations or studies. The GAO may also be asked to comment on Congressional legislation or on appraisals by other agencies. Other functions not tied directly to Congress include settling certain claims against the Federal Government or dealing with protest actions by Government contractors. 
CONGRESSIONAL RESEARCH SERVICE

The Congressional Research Service of the Library of Congress

provides reference, research, analytical, and information services to members of Congress on environmental and other issues. 
SECTION IV

FEDERAL EXECUTIVE AND OTHER FEDERAL ORGANIZATIONS 


\section{SECTION IV}

FEDERAL EXECUTIVE AND OTHER FEDERAL ORGANIZATIONS

Several organizations in the executive branch of the Federal government are concerned with environmental, health and safety (EH\&S) effects related to energy technology development. Offices and bureaus which have significant functions (e.g., technology research and development [R\&D], standards development and enforcement, policy assessment and review, and/or information storage and dissemination) are described in this section. R\&D and standards development and enforcement activities are emphasized. A summary of executive branch responsibilities is presented in Exhibit 8.

COUNCIL ON ENVIRONMENTAL QUALITY, EXECUTIVE OFFICE OF THE PRESIDENT The Council on Environmental Quality (CEQ) consists of three members appointed by the President to formulate and recommend national policies for enhancing the nation's environmental quality. Council members are supported by an energy program staff responsible for assessing the environmental impacts of Federal programs for energy development and use. $C E Q$ issued guidelines for developing an Environmental Impact Statement (EIS), pursuant to the National Environmenta1 Policy Act of 1969. However, a 1977 Presidential Executive Order directed $C E Q$ to issue formal regulations for EIS preparation, and for other procedures relating to NEPA implementtation. Draft regulations were issued in June of $1978 *$. 


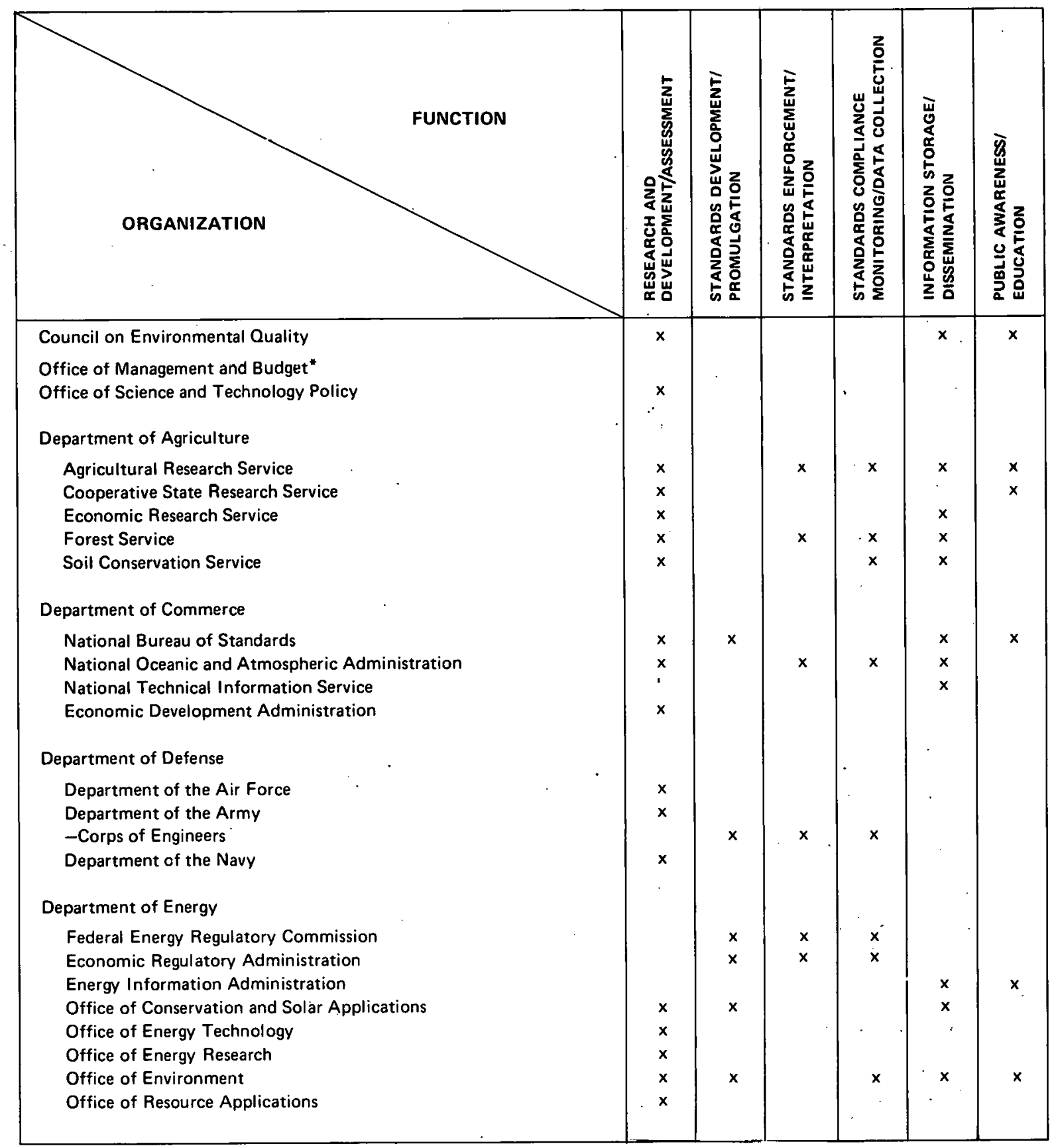

"Has primarily oversight function.

EXHIBIT 8
FEDERAL ÉXECUTIVE ORGANIZATIONS

ENERGY/ENVIRONMENTAL FUNCTIONS 


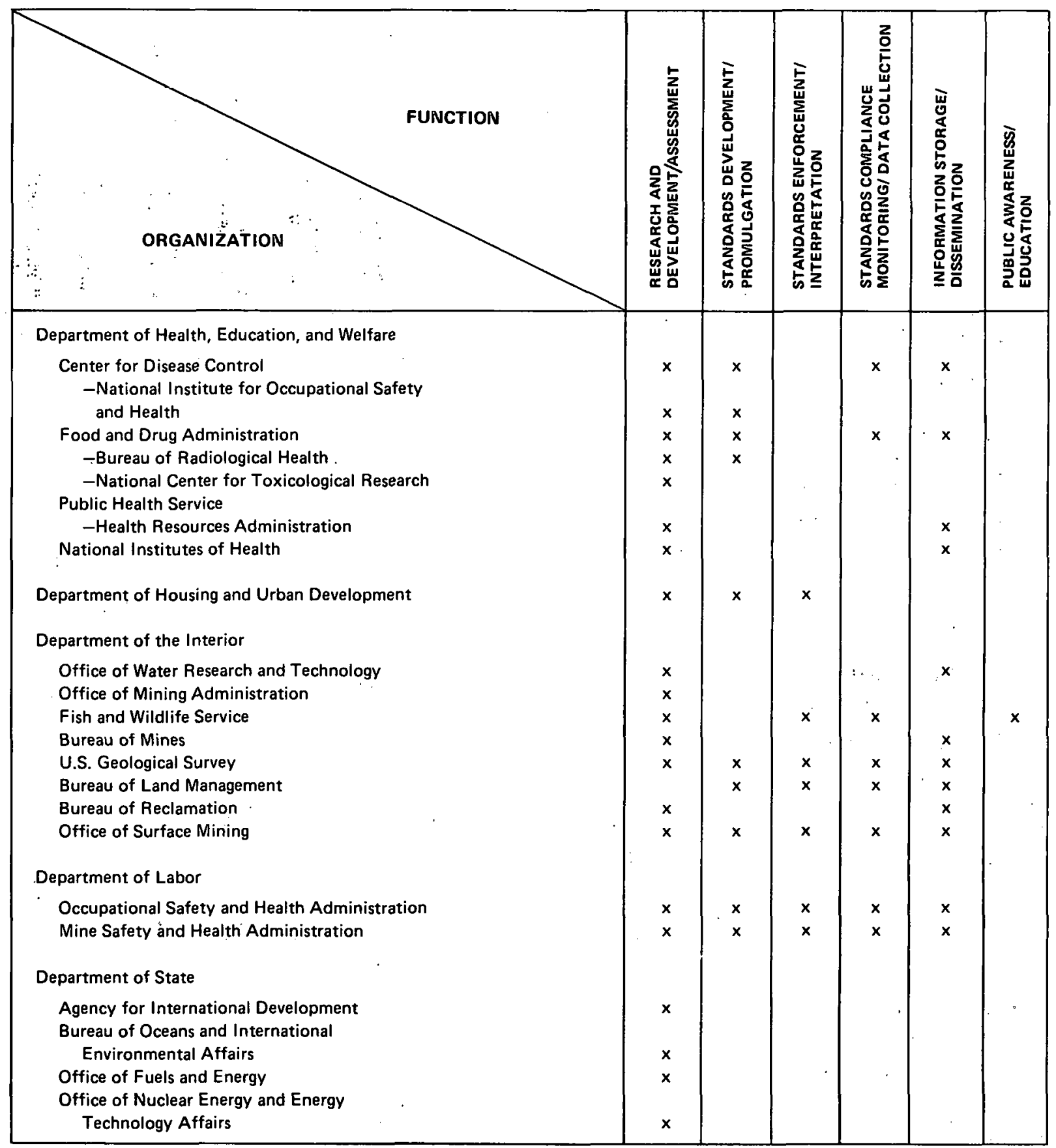

EXHIBIT 8 (CONT.)

FEDERAL EXECUTIVE ORGANIZATIONS

ENERGY/ENVIRONMENTAL FUNCTIONS 


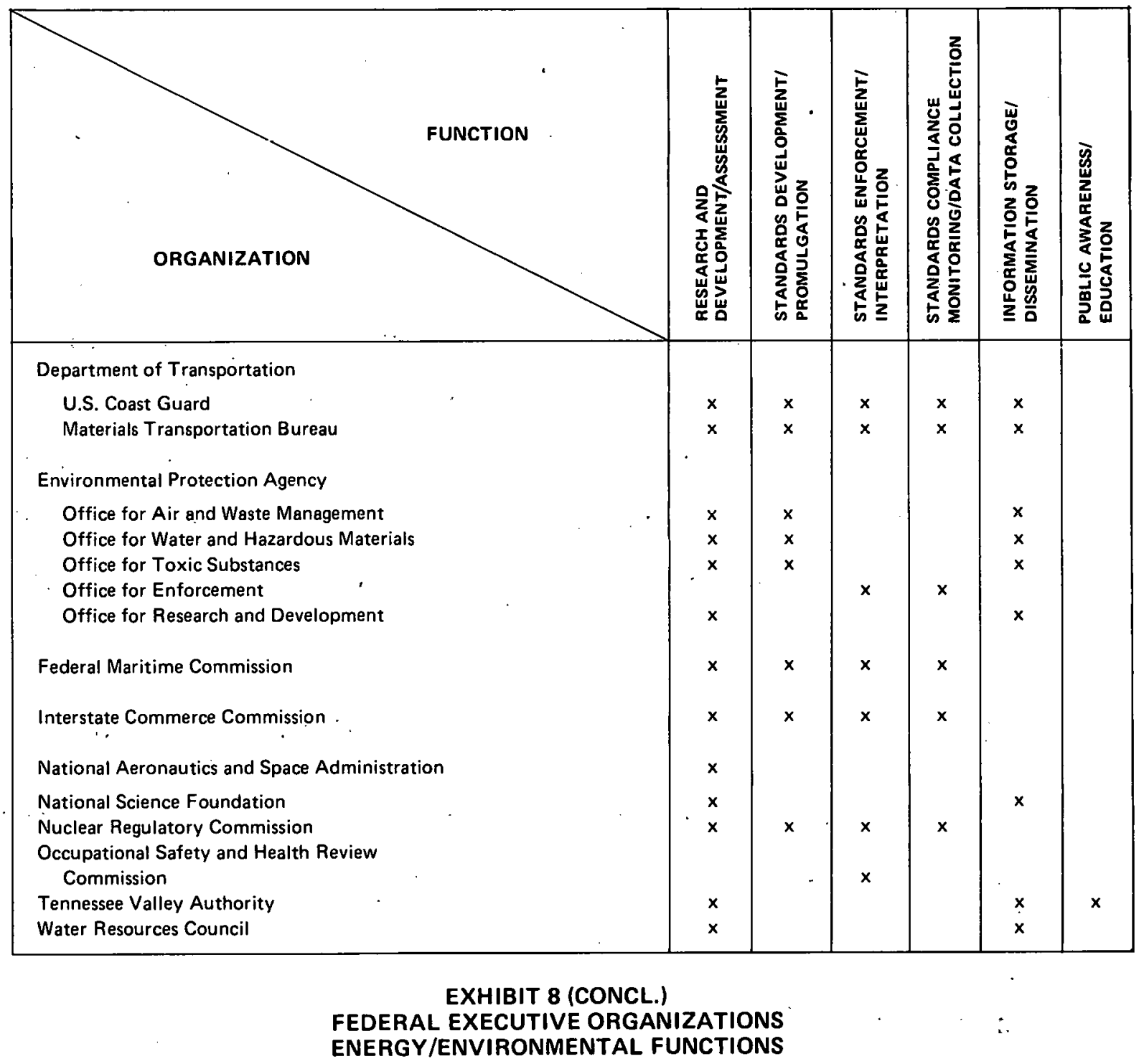

i. 
Final regulations will be issued at the end of the public commenting period. CEQ also makes arrangements with other Federal agencies and academic institutions to conduct research and assessment on energyrelated environmental issues.

OFFICE OF MANAGEMENT AND BUDGET, EXECUTIVE OFFICE OF THE PRESIDENT The Office of Management and Budget (OMB) is responsible for. administering the Federal budget. In this capacity, OMB periodically evaluates the effectiveness with which energy and environmental programs are managed, and advises the President on energy/environmental policy issues. ОМB also coordinates data policy in the executive branch.

OFFICE OF SCIENCE AND TECHNOLOGY POLICY, EXECUTIVE OFFICE OF THE PRESIDENT

The Office of Science and Technology Policy advises the President on a wide range of scientific, engineering, and technological subjects, including EH\&S issues.

DEPARTMENT OF AGRICULTURE

The Department of Agriculture (USDA) has several EH\&S responsibilities. Although not directly related to energy technologies, some may have significant effects on the development of energy resources. Each office listed below has research and development programs. Regulatory functions are limited to cooperation with state and local 
officials in environmental monitoring. Included here are soil mon-

itoring programs conducted by the Soil Conservation Service. Local

law enforcement on National Forest System lands is undertaken by

the Forest Service. EH\&S programs are conducted by the following

offices.

1. The Agricultural Research Service (ARS) provides research and assessments designed to help farmers meet the food needs of the American people while conserving critical natural resources. Research designed to make more effective use of soil and water resources has several energy-related implications. Other ARS research involves the recovery of energy from agricultural waste products.

2. The Cooperative State Research Service administers Federal grants for research in agriculture and forestry.

3. The Economic Research Service (ERS) studies the use, conservation, development, and control of natural resources. ERS is concerned with the way natural resources contribute to local, regional, and national economic growth. Analysis of environmental issues is an important element of the ERS mission.

4. The Forest Service (FS) administers national forests, grasslands, and land utilization projects. It conducts a program of energy management which takes into consideration surface effects and other environmental impacts of mineral leasing and development. FS also monitors air quality, manages water resources, and enforces laws, standards, and regulations on National Forest lands. The Service conducts research to support forest-related activities and participates in watershed and river basin programs.

5. The Soil Conservation Service (SCS) is responsible for developing and conducting a national soil and water conservation program. It is actively involved in river basin surveys and investigations, watershed planning, flood prevention programs, non-point source pollution control, environmental improvements, and rural community development. SCS also monitors soil for radionuclides. 
DEPARTMENT OF COMMERCE

Energy-related environmental activities within the Department of Commerce (DOC) include the development of standards, basic and applied research, environmental monitoring, and information storage and dissemination.

DOC research efforts are conducted by the National Oceanic and Atmospheric Administration (NOAA) and the National Bureau of Standards (NBS). NOAA divisions include the National Environmental Satellite Service, which conducts a program of research relating to the earth's oceans and inland waters, atmosphere, and space environment, and the National Marine Fisheries Service, which does research on the resources of the sea. NBS does research, at the request of other agencies, to differentiate among proposed standards and to détermine their enforceability. No regulatóry authority is exercised by the Department of Commerce except for some limited NOAA involvement in standards development.' Most environmental responsibilities are assigned to one of the following DOC offices.

1. The National Bureau of Standards (NBS) conducts research, provides a basis for national measurement systems, and provides various technical services including the development of guidelines for the protection of health and safety. The National Standards Laboratory, National Engineering Laboratory, and Institute for Computer Science and Technology are under the auspices of NBS.

2. The National Oceanic and Atmospheric Administration (NOAA) is concerned with the management, use, and conservation of animal and mineral resources in the marine environment. NOAA also monitors and predicts characteristics of the physical environment (including geological disturbances and upper and lower atmospheric phenomena) and warns against impending environmental 
hazards. NOAA is directly involved in offshore oil development, examining the consequences of oil spills and power plant installations, and exploring the development of novel oceanic power sources. The following organizations are part of NOAA: The National Ocean Survey, the National Weather Service, the National Marine Fisheries Service, the National Environmental Satellite Service, Environmental Research Laboratories, the Environmental Data Service, the Office of Sea Grants, and the Office of Coastal Zone Management.

3. National Technical Information Service responsibilities include the dissemination, by sale, of EH\&S information related to energy development.

4. The Economic Development Administration (EDA) carries out most of the provisions of the Public Works and Economic Development Act of 1965. EDA has established multicounty economic planning commissions to coordinate the development of energy, water, and natural resources. EDA is authorized to provide economic deve1opment funds to states, counties, municipal authorities, and Indian tribes. EDA also funds technical assistance studies and grant applications aimed at minimizing economic dislocations caused by concentrated energy development activities in rural, undeveloped areas.

\section{DEPARTMENT OF DEFENSE}

The Department of Defense (DOD) is the largest single governmental user of energy in the United States and, consequently, administers R\&D programs which address problems such as energy conservation, synthetic fuels characterization, systems design, and engine efficiency. Environmental research concerned. with nonionizing radiation (i.e., electromagnetic radiation) is being pursued by the Army, Navy, and Air Force. The Navy also has been involved in cleaning up oil spills and related shipboard wastes, and has studied EH\&S issues associated with nuclear-propelled missiles and with shipyards. The major environmental responsibilities of DOD, including 
regulatory and research functions, however, are carried out by the Ü.S. Army Corps of Engineers.

The U.S. Army Corps of Engineers is concerned primarily with surface-water resources. The Corps conducts research, develops criteria and standards, issues permits, and manages and monitors navigable U.S. waters. The Corps also provides planning assistance for water pollution abatement projects. As part of its regulatory function, the Corps grants permits for construction in, on, under or above any navigable waters of the U.S., for dredging waterways or altering adjacent wetlands, and for the disposal of dredged materials.

\section{DEPARTMENT OF ENERGY}

The Department of Energy (DOE) was created to consolidate energy programs previously scattered among several Federal agencies. DOE's major economic regulatory responsibilities are vested in the Federal Energy Regulatory Commission and the Economic Regulatory Administration. The Office of Conservation and Solar Applications is responsible for promulgating standards necessary to implement national conservation objectives. The Office of Resource Applications (RA) develops standards as required by the Energy Resource Leasing Program and by RA's power marketing functions. The Office of Environment is responsible for insuring compliance with 'DOE's environmental goals, often in conjunction with other offices. Energy/environmental research is conducted by the Offices of Conservation and Solar 
Applications, Energy Research, Energy Technology, Environment, and

Resource Applications. Each of these offices is discussed below.

1. The Federal Energy Regulatory Commission (FERC) is an independent organization within DOE. The FERC regulates the price of natural gas sold at the wellhead, the transmission charge levied by the operators of petroleum and natural gas pipeline's, the price. charged for electric energy transmission and sale, and electric energy interconnections. The Commission exercises authority over hydroelectric power licensing, power and gas company mergers, and natural gas curtailment.

2. The Economic Regulatory Administration (ERA) administers DOE regulatory programs not under the authority of the Federal Energy Regulatory Commission. These include oil pricing, allocation and imports; conversion of oil- and gas-fired utility and industrial facilities to coal; natural gas import/export controls; natural gas curtailment priorities and emergency allocations; regional coordination of electric power system planning and reliability of bulk power supply; and emergency and contingency planning. ERA also insures compliance with existing regulations and is responsible for carrying out necessary new regulatory programs.

3. The Energy Information Administration (EIA) is responsible for the collection, validation, processing, analysis, and publication of data regarding energy reserves, financial status of energyproducing companies, energy production, demand and consumption levels, and other areas. EIA publishes and distributes these data to the government and the public.

4. The Office of Conservation and Solar Applications (CS) conducts conservation and technology application programs designed to improve energy system efficiency. In addition, cS conducts demonstration programs to hasten commercialization of solar and conservation technologies. Both conservation and solar applications programs produce environmental impacts.

5. The Office of Energy Technology (ET) is responsible for implementing solar, geothermal, fossil, nuclear, fusion and other technological R\&D programs. ET will also formulate strategies for naval reactor development and mid- and long-term energy technology development. The office also manages nuclear waste storage activities and acts as the primary DOE source of energy technology information. 
6. The Office of Energy Research (ER) provides advice to the DOE Secretary with respect to physical research programs, education and training research, and financial mechanisms for research support. ER's other responsibilities include production of gap/ overlap analyses for DOE research programs, performance of fundamental research not conducted by the Office of Energy Technology, and provision of staff support for the Field and Laboratory and the R\&D Coordination Councils.

7. The Office of Environment (EV) is responsible for most EH\&S aspects of DOE's programs. EV insures DOE support for environmental goals by overseeing compliance with the National Environmental Policy Act and other environmental legislation. Further, EV performs energy system assessments and policy analyses from the perspective of environmental protection, develops health and safety standards, establishes decontamination/decommissioning policy, and appraises the adequacy of operational safety and health measures for DOE activities. EV identifies environmental issues, evaluates control technology, and where environmental data are incomplete, EV undertakes appropriate R\&D.

8. The Office of Resource Applications (RA) works to insure the commercial availability of energy supplies which are economically and environmentally attractive. RA performs this function in conjunction with CS.' Also included under RA are the power marketing functions formerly under the Department of the Interior (DOI), the marketing and transmission functions formerly performed by the Bureau of Reclamation in DOI, management responsibility for the strategic oil stockpile and the nation's enriched uranium production, and some aspects of energy resource leasing procedures on Federal lands, including the promulgation of regulations.

DEPARTMENT OF HEALTH, EDUCATION, AND WELFARE

Department of Health, Education, and Welfare (HEW) EH\&S responsibilities include the development of criteria and standards, environmental monitoring, basic and applied research, and information dissemination.

Research is conducted at several agencies of HEW. Most research programs at the National Institute for Occupational Safety and 
Health and the Food and Drug Administration are conducted to provide

a basis for standard-setting. R\&D programs are also conducted at the

National Center for Toxicological Research and the National

Institutes of Health.

HEW regulatory responsibilities include only the promulgation of

standards. Enforcement of occupational health and safety standards

is provided by the Department of Labor, while the Department of

Agriculture is responsible for enforcing FDA standards for food and

drugs.

Major HEW agencies involved in EH\&S issues include the follow-

ing.

1. The Center for Disease Control (CDC) administers national programs for the prevention and control of communicable and vector-borne diseases and other preventable conditions. CDC develops criteria for recommended occupational safety and health standards and conducts research to support these standards. The National Institute for Occupational Safety and Health (NIOSH), a part of the CDC, works to insure safe and healthful working conditions in all occupations.

2. The Food and Drug Administration (FDA) performs research and develops standards on the composition, quality, nutrition, and safety of foods, food additives, colors, cosmetics and drugs. The Bureau of Radiological Health, within FDA, conducts programs to reduce the exposure of humans to hazardous ionizing and nonionizing radiation. The Bureau develops radiation exposure standards, and conducts health effects research. The National Center for Toxicological Research (NCTR), currently within FDA, conducts research programs to study the biological effects of potentially toxic chemical substances found in the environment. NCTR's investigations emphasize long-term, low level exposures to hazardous substances.

3. The Health Resources Administration, part of the Public Health Service, collects, analyzes, and disseminates health data via the National Center for Health Statistics. 
4. The National Institutes of Health (NIH) conducts and supports biomedical research into the causes, prevention, and cures of diseases. The National Cancer Institute (NCI) and the National Institute of Environmental Health Sciences (NIEHS) are two examples of the several specialized NIH research centers which address energy/environmental topics.

DEPARTMENT OF HOUSING AND URBAN DEVELOPMENT

Most EH\&S responsibilities in the Department of Housing and Urban Development (HUD) involve the development and enforcement of standards. For example, pursuant to the Energy Conservation and Production Act of 1976, HUD has developed standards for residential and commercial buildings, which will be promulgated by DOE. HUD will then enforce the standards to encourage the use of non-depletable energy supplies. HUD is also responsible for enforcing health (sanitary) codes on Federally-funded projects.

DEPARTMENT OF THE' INTERIOR

The Department of the Interior's (DOI) involvement in energyrelated EH\&S problems comes in the form of research and development, resource management, environmental impact mitigation, criteria. development, standards enforcement, and environmental monitoring. Research activities at DOI are performed by the Bureau of Mines (minerals and fuels), the Fish and Wildlife Service (fish and wildlife resources), and the Geological Survey (mineral and water resources). Although the Office of Water Research and Technology administers basic and applied research programs, these are carried 
out by means of grants and contracts; no in-house research is

performed.

Regulatory authority is vested in the Geological Survey and the

Bureau of Land Management, which cooperate in leasing and administer-

ing Federal lands. Surface mining activities, including surface dis-

turbances associated with deep mines, are regulated by the office of

Surface Mining.

1. The Office of Water Research and Technology researches critical water resource problems including the environmental impacts of strip mining, waste heat emission, acid mine drainage, and the socioeconomic effects of fossil fuel development. Water conservation, water supply modeling, and desalination processes also receive major emphasis.

2. The Ocean Mining Administration supervises environmental studies relating to the development of mineral resources in the oceans.

3. The Fish and Wildlife Service (FWS) is responsible for managing fish and wildlife resources. The Service monitors ecosystems for toxic materials and thermal pollution, and also performs ecological studies and environmental impact assessments. FWS also conducts resource conservation programs. Within FWS, the Office of Biological Services administers several environmental programs dealing with oil shale, coal, and geothermal resource development. Coastal resources, western water allocation, and power-plant siting issues also come under the Service's purview.

4. The Bureau of Mines (BOM) is the major Federal agency for resolving issues and problems associated with the extraction, processing, use, and recycling of the nation's mineral resources. Research programs at BOM include the demonstration of mined land reclamation technologies.

5. The U.S. Geological Survey (USGS) is responsible for classifying all public lands and for examining all geological structures, mineral resources, and products in the national domain. USGS conducts research on the extent and quality of the nation's surface and subsurface water $r_{7}$ resources and investigates seismic disturbances. The Survey also administers mineral leases. (i.e., geothermal, oil, shale, mining and oil and gas leases) on Federal lands in consultation with the Bureau of Land Management. 
6. The Bureau of Land Management (BLM) is responsible for managing the environmental quality of all public land. BLM administers public lands in conjunction with USGS and is responsible for granting leases for coal mining, regulating grazing and timber rights, and granting permits for transportation across public lands. BLM also prepares environmental impact statements,

$\because \because$ reclamation assessments, and conducts environmental baseline and monitoring activities related to energy development.

7. The Bureau of Reclamation (BR) is responsible for helping state and local governments, and other Federal agencies improve the quality of life by developing water and related land resources. BR programs significantly affect the development of energy resources in the arid and semi-arid western states, because the Bureau investigates and regulates the use of water and related resources.

8. The Office of Surface Mining was created in 1977 to develop and enforce standards' pursuant to the Surface Mining and Reclamation Act of 1977. Of particular significance are the office's regulations for mined land reclamation.

\section{DEPARTMENT OF LABOR}

The Department of Labor (DOL) approaches its health and safety regulatory responsibilities through two distinct Administrations.

1. The Occupational Safety and Health Administration (OSHA) develops and enforces occupational health and safety standards. OSHA can issue citations and penalties for noncompliance.

2. The Mine Safety and Health Administration is responsible for developing and enforcing safety and health standards for mineral extraction operations. It coordinates its activities with the safety and health research programs conducted by other Federal agencies and the mining industry.

DEPARTMENT OF . STATE

Several branches of the Department of State are marginally involved in EH\&S issues related to energy development. The global scope of energy-related issues has led to a more active role for the 
Department of State in the development of international energy policy and cooperative agreements with foreign governments. Each organization described below must account for the environmental implications of its programs.

1. The Agency for International Development funds the development of energy technologies in underdeveloped countries.

2. The Bureau of Oceans and International Environmental Affairs is responsible for managing a broad range of global policy. issues related to oceans, fisheries, nuclear technology, and new energy technology.

3. The Office of Fuels and Energy is responsible for U.S. participation in the International Energy Agency.

4. The Office of Nuclear Energy and Energy Technology Affairs helps foster long-term energy development cooperation among nations, with particular emphasis on nuclear energy safeguards and security.

\section{DEPARTMENT OF TRANSPORTATION}

The Department of Transportation's (DOT) major energy-related responsibilities are discharged through the U.S. Coast Guard and the Materials Transportation Bureau. Both offices have major regulatory functions.

1. The U.S. Coast Guard enforces the 0il Pollution Act of 1961. In this capacity, the Coast Guard administers the Pollution Fund to insure immediate cleanup of oil or other hazardous polluting substances spilled into navigable U.S. waters. The Coast Guard also is responsible for licensing and regulating deep water ports that transfer oil from tankers to shore facilities.

2. The Materials Transportation Bureau regulates the transportation of hazardous materials, including those moved through pipelines. 
ENVIRONMENTAL PROTECTION AGENCY

The Environmental Protection Agency (EPA) was organized to coordinate governmental efforts to protect and enhance the environment. The Agency strives to control and abate pollution by integrating its research, monitoring, regulatory, and enforcement functions... In addition, EPA coordinates and supports antipollution efforts by other Federal agencies; state, local, private, and public groups; educational institutions; and individuals. Because EPA's environmental responsibilities are so broad, almost. all its activities are in some way energy-related. The Offices of Air and Waste Management, Water and Hazardous Materials, Toxic Substances, Enforcement, and Research and Development are among those most closely involved with energyrelated environmental research.

EPA is the chief national regulatory authority in the areas of air and water pollution, solid waste, toxic substances, and pesticides. Therefore, regulatory and/or monitoring activities are an essential part of each of EPA's technical programs.

Most EPA research and development activities are conducted by the Office of Research and Development, which manages environmental research laboratories and programs, ànd provides information dissemination services. Other EPA offices generally conduct research and development programs to support their regulatory and other functions. 
EPA offices are organized along functional lines. Major

programs with EH\&S responsibilities ăre described below.

1. The Office for Air and Waste Management develops national programs, policies, and regulations to control air pollution; and establishes national standards for air quality and emissions standards for new stationary sources. The office also regulates hazardous pollutants, noise sources and hazardous waste land disposal. Its monitoring activities cover air pollutants, noise, and radiation levels. Other activities include technical direction, support, evaluation and training efforts in the fields of air quality and pollution, radiation protection, and waste management and utilization. These programs are conducted by the Offices of Air Quality Planning and Standards, Mobile Source Air Pollution Control, Noise Abatement and Control, Radiation Programs, and Solid Waste.

2. The Office for Water and Hazardous Materials is responsible for regulating and monitoring water quality, effluents, and pesticide levels--in addition to investigating pesticide accidents. Other activities include a coordinated effort to restore the Nation's waters by developing national programs and technical policies, and by providing technological assistance and training in the water quality field. Research activities include the establishment of tolerance levels for pesticides which are present in the food chain. These programs are conducted by the offices of Pesticides Programs, Water Planning and Standards, Water Program Operations, and Water Supply.

3. The Office for Toxic Substances (OTS) monitors and regulates substances deemed hazardous to humans or the environment. OTS develops national abatement strategies and coordinates assessment and control activities with other agencies.

4. The Office of Enforcement conducts all EPA enforcement in the fields of air, water, pesticides, solid waste, etc. Each of the other offices is represented by a program in the office of Enforcement.

5. The Office for Research and Development handles EPA's research programs through the Offices of Air, Land and Water Use; Energy, Minerals and Industry (OEMI); Health and Ecological Effects; and Monitoring and Technical Support. Other activities include supervision and technical guidance for EPA's national laboratories; management of selected demonstration programs; planning 
for EPA environmental quality programs; dissemination of information resulting from EPA research, development, and demonstration; and coordination of efforts with other Federal agencies, states, and public bodies. A specific example of the latter is the Interagency Energy/Environment R\&D Program, a multi-agency Federal program planned and coordinated by OEMI.

FEDERAL MARITIME · COMMISSION

The Federal Maritime Commission (FMC) regulates the waterborne offshore commerce of the U.S. and its territories. FMC promulgates rules and regulations to interpret, enforce, and assure compliance with shipping statutes by common carriers, including carriers of energy supplies. A more specific environmental responsibility is the issuance of certificates of financial responsibility to insure that owners or operators of ships over 300 gross registered tons carry insurance to reimburse the Federal Government for cleanup costs incurred as a result of an oil spill in.U.S. navigable waters, adjoining shorelines, or waters of the contiguous zone.

\section{INTERSTATE COMMERCE COMMISSION}

The Interstate Commerce Commission (ICC) has jurisdiction over interstate surface transportation. The Commission's energy-related environmental responsibilities include authority for rail and pipeline movement of coal and oil, approval for rail line construction, regulation of railroad freight charges, assurance of adequate rail transportation for coal mine production, and collection of data on rail shipment, pipeline movement, and water-borne transportation of coal, oil and natural gas. 
NATIONAL AERONAUTICS AND SPACE ADMINISTRATION

Most National Aeronautics and Space Administration (NASA) EH\&S activities are conducted by the Office of Applications, which is responsible for applying space-related technology for the benefit of mankind. NASA concentrates on the areas of weather and climate. modification, pollution monitoring, earth resources surveys, ocean physics, and solar and wind technology.

\section{NATIONAL SCIENCE FOUNDATION}

The National Science Foundation supports basic and applied research and education in the sciences. Energy-related EH\&S issues. are considered in three of the Foundation's Directorates. Environmental biology studies are sponsored by the Directorate for Biological, Behavioral and Social Sciences. Advanced environmental, energy, and resources research and technology programs are conducted by the Directorate for Research Applications, while the policy aspects of energy, resources, and the environment are studied by the Directorate for Scientific, Technological and International Affairs.

NUCLEAR REGULATORY COMMISSION

The Nuclear Regulatory Commission (NRC) licenses and regulates the uses of nuclear energy, primarily nuclear power generation, to protect public health and safety and the environment. NRC licenses nucleàr reactors and other facilities and all handling of nuclear 
materials, develops and enforces standards and regulations, and manages research deemed necessary to support these functions. Major EH\&S activities are carried out by the office of Nuclear Reactor Regulation, the Office of Nuclear Material Safety and Safeguards, the Office of Nuclear Reactor Research, the Office of Standards Development, and the Office of Inspection and Enforcement.

OCCUPATIONAL SAFETY AND HEALTH REVIEW COMMISSION

The Occupational Safety and Health Review Commission is an adjudicatory agency that reviews cases sent to it by the Department of Labor (DOL) when disagreements arise over the results of safety and health inspections performed by DOL.

\section{TENNESSEE VALLEY AUTHORITY}

The Tennessee Valley Authority (TVA) is a Federally-owned corporation which conducts a unified program of resource development and research to support economic growth in the Tennessee Valley Region. TVA's major activities include flood control, navigation development, electric power production, fertilizer development, recreation improvement, forestry and wildlife management, and waste heat utilization.

WATER RESOURCES COUNCIL

The Water Resources Council (WRC) is responsible for evaluating the adequacy of water supplies to meet requirements in each water resource region in the U.S. The Council studies the relation of 
regional or river basin plans and programs to the requirements of larger regions of the nation. WRC also analyzes the adequacy of administrative and statutory procedures for coordinating water and related land resources policies and programs in all Federal agencies. At the request of the Department of Energy (DOE), the Council assesses water resource requirements and water supply availability for any nonnuclear energy technology or any probable combinations of technologies which the Federal government is developing. WRC prepares water resource assessments for all DOE demonstration projects which may have a significant impact on water resources, and for all Federally-funded energy technology commercial applications. Further, the Council prepares a biennial assessment of regional and national water resource availability for energy development. 
.

0

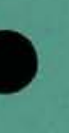

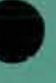

.

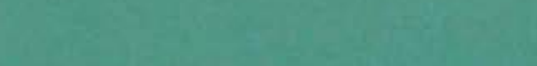

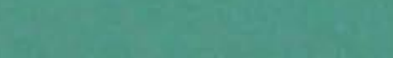
更

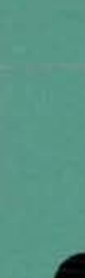




\title{
SECTION V \\ QUASI-OFFICIAL AGENCIES
}

\begin{abstract}
Several agencies which provide assistance to the Federal establishment are not directly funded by the Government. Rather, they are supported through contracts, grants, and other contributions. Some functions of these agencies may affect or be affected by energy technology developments. The agencies often play a significant role in resolving the complex environmental, health, and safety (EH\&S) issues associated with developing technologies.

These quasi-official agencies include the National Academy of Sciences (NAS), and NAS subsidiaries such as the National Academy of Engineering, the National Research Council, and the Institute of Medicine. Also included is the Smithsonian Institute. Each agency performs only research; none exercises regulatory authority. Quasiofficial agencies, however, may become involved in research to support standard-setting at the request of a regulatory agency.
\end{abstract}

NATIONAL ACADEMY OF SCIENCES

The National Academy of Sciences (NAS) is a private society established by Congress to serve as an official advisor to the Federal Government on questions of science and technology. It advises Congress and Government agencies, including DOE and EPA. In this way, NAS may be involved in major EH\&S energy-related research, 
assessments, and standards development. At times, NAS is also the vehicle through which the United States participates in international environmental matters.

NATIONAL ACADEMY OF ENGINEERING

The National Academy of Engineering (NAE), established under the charter of NAS, encourages engineering research, and advises the Federal Government. Through NAE, the nation's most eminent engineers participate in environmental and other engineering programs.

NATIONAL RESEARCH COUNCIL

The National Research Council (NRC) is the principal operating agency of NAS and NAE. It was organized to encourage a broader representation of scientists and technologists in analytical studies. Another NRC purpose is to stimulate scientific research and to foster the application of resultant findings. In recent years, NRC has addressed issues such as U.S. energy requirements, the effectiveness of technological research, and standards for automobile emissions. Various committee studies on noise effects, advanced energy storage systems, nuclear and alternative energy systems, animal models, genetics, laboratory animal tumors, biophysics, biological effects of ionizing low frequency radiation, toxic substances, water, and climate reflect NRC's wide-ranging interests in the EH\&S effects of energy technology development. 


\section{INSTITUTE OF MEDICINE}

The Institute of Medicine was chartered by NAS to identify policy issues and problems relating to health and medicine, and to conduct research on these subjects. The Institute provides a forum for consideration of EH\&S issues by advising the Federal government and other agencies on these matters, by establishing liaison with major scientific and professional societies in the field, and by disseminating information to the public and to relevant professional groups.

\section{SMITHSONIAN INSTITUTION}

As an independent trust establishment, the Smithsonian Institution performs fundamental research, publishes research findings, participates in international exchanges of publications, and engages in cooperative research that may include energy-related EH\&S areas. The scientific programs of the Chesapeake Bay Center for Environmental Studies involve estuarine processes, watershed monitoring, and terrestrial ecology. The Smithsonian's National Museum of Natural History performs fundamental research and furnishes the results to the academic and scientific communities. The Museum also plans programs leading to predictive ecology and environmental management. Basic problems of photobiology at the cellular, subcellular, and . molecular levels are studied at the Radiation Biology Laboratory. Research activities at the Astrophysical Observatory and studies 
at the Tropical Research Institute are some of the other programs in which the Smithsonian Institution addresses EH\&S issues. The Smithsonian Science Information Exchange is a primary source for information on research in progress, including studies on the environmental effects of energy technology. 


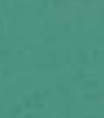
P

.

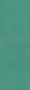

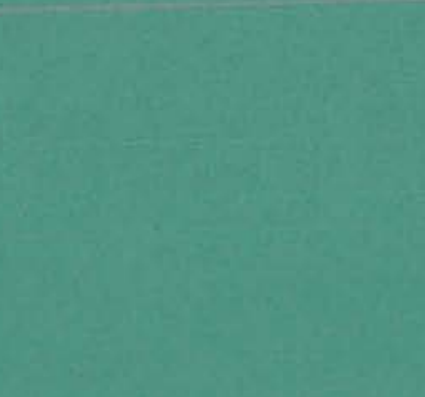

tax 
SECTION VI

TIIE JUDICIARY

The United States Court System is composed of State and local courts on one hand, and Federal courts on the other. Most environmental issues resulting from energy technology development are adjudicated by the Federal Courts.

The Constitution limits the jurisdiction of Federal Courts to:

- controversies to which the United States shall be a party, including situations where an agency or officer either sues someone or is sued;

- controversies between two or more states or citizens thereof, to insure impartiality in cases involving multiple jurisdictions; and

- cases arising under the U.S. Constitution, laws and treaties.

Within the above criteria, Congress may designate that certain cases (often involving nominal damages) may be decided at the state level, or may indicate which courts within the Federal judiciary should have primary and appellate jurisdiction. The three primary elements of the Federal court system are the District Courts, the Court of Appeals, and the Supreme Court.*

* Initial review of Federal agency decisions is normally in the appropriate U.S. District Court, with appellate review in the Court of Appeals and the Supreme Court. In certain instances, Congress provides for the initial review at the Court of Appeals level (e.g., for review of final decisions of certain regulatory agencies) and may designate that appeals of agency decisions be referred to a specific appellate circuit (e.g., the District of Columbia Circuit has exclusive jurisdiction of appeals concerning interim regulations established under the Surface Mining Control and Reclamation Act of 1977). 
Judicial review of agency decisions may address procedural or substantive matters. Procedural matters relate to the overall process by which Federal decisions are reached. Due process protection is afforded to affected or interested parties in a broad sense by the Administrative Procedure Act (APA) and, in a narrower sense, by regulatory procedures set forth in specific statutes and agency procedures. The APA establishes the maximum procedural requirements which Congress is willing to impose upon agencies in rulemaking and adjudicatory proceedings. At their discretion, agencies are permitted to grant additional procedural rights, and often do in internal regulations. However, as a general rule, the courts are not free to impose stricter standards where agencies choose not to.

Substantive review of agency decisions addresses the actual decision, rather than the process by which the decision was reached. Agency actions typically are based on a balancing of factors, such as environmental and economic costs and benefits, the need to foster economic or domestic energy growth, or political and balance of trade issues. The courts can decide whether the actual decision was arbitrary, capricious, or not in accordance with the law. They are not permitted, however, to substitute their judgment for that of the agency.

The Federal judiciary also decides enforcement actions. In the first instance, such actions may be brought by government agencies or citizens; in the second, by groups appealing earlier regulatory decisions. The courts may impose criminal or civil penalties as provided by applicable statutes. $\quad 52$ 
The Land and Natural Resources Division of the Justice Department represents the Federal government in cases where it is a plaintiff or defendant. This Division handles all suits relating to real property (including land, water, the outer continental shelf, marine and other natural resources, and environmental protection). These matters include condemnation proceedings for the acquisition of property and actions to recover damages, to determine boundaries, to establish water rights, to protect water resources, to establish mineral rights, and to abate pollution. The Division is also responsible for criminal prosecutions for air and water pollution. The Justice Department is usually assisted by the General Counsel's or Solicitor's office within an affected agency.

State courts have broad jurisdictional authority to decide cases involving state and local exercise of police/public safety powers. There is a basic assumption that the historic police powers of the states are not superseded by Federal laws unless that was the clear and manifest purpose of Congress. State statutes and court jurisdiction are void to the extent they actually conflict with a valid Federal statute.*

\footnotetext{
*For example, in Ray v. At lantic Richfield Co., __.S. U. (1978), The Supreme Court found that the Ports and Waterways Safety Act of 1972 established a comprehensive mechanism for control of shipping in inland waters. A state law seeking to establish concurrent jurisdiction was deemed preempted by the 1972 Act to the extent compliance with both Federal and state regulations is a physical impossibility or the state laws present an "obstacle" to the accomplishment and execution of the full purposes and objectives of Congress.
} 
THIS PAGE

\section{WAS INTENTIONALLY LEFT BLANK}



At the state and local levels, numerous government agencies perform functions that are similar in many ways to those of their Federal counterparts. The title, scope of responsibility, and organizational structure of these government bodies differ greatly. Various committees in state legislatures oversee the authorization, appropriation, regulatory, research, and other related activities of the state and local executive branch agencies. Many types of executive departments, commissions, councils, boards, research units, and quasi-official citizen groups administer statutes enacted by state legislatures. When a statute permits agency discretion, or an improved technical basis is needed for enforcement, agency regulations are often promulgated in a manner similar to those of Federal agencies.

In recent years, Congress has provided Federal agencies with the authority to set standards and perform other regulatory activities in EH\&S matters. In many cases, state authority predates that of the Federal government, and some adjustments by state agencies have been necessary. For example, some state mine health and safety standards have been amended to conform to those promulgated by Federal agencies.

In general, the state role has evolved from one of primary enforcement to one of supplementary enforcement, or partnership with 
the Federal government. The exact nature of Federal-state relationships may vary considerably, according to the media (e.g., air, water, land) or activity involved, and according to Congressional intent. In virtually all cases, however, minimum standards for pollutant loadings or health and safety measures are promulgated by Federal agencies pursuant to specific Federal statutes. Then, consistent with these minimum standards, some form of cooperation or delegation of authority is established between state and Federal agencies.

Variations in state roles can be illustrated by examining the provisions of a few statutes. The Clean Air Act, as amended, requires each state to submit a State Implementation Plan (SIP) to the Environmental Protection Agency (EPA) for approval of regional air quality emissions standards for existing air pollution sources. After approving the SIP's, EPA conferred enforcement authority upon certain state and local bodies. EPA has also promulgated New Source Performance Standards for additional protection of air quality. In certain instances, states have adopted more stringent standards, as is their legally enforceable prerogative. Under the Federal Water Pollution Control Act, EPA approves ambient standards for interstate bodies of water, and establishes maximum effluent standards for specific pollutants and individual industries by means of the National Pollutant Discharge Elimination System (NPDES). The NPDES requires permits for process water discharges. State agencies which 
meet EPA's administrative specifications (e.g., level of authority, extent of fines, etc.) may issue and enforce NPDES permits.

The new Surface Mining Control and Reclamation Act of 1977, which establishes reclamation standards for mined land, provides that the Federal government may delegate enforcement authority to states where sufficient technical personnel, funding, and sanctions are available. By contrast, the Federal Coal Mine Health and Safety Act has no explicit provisions for standard setting and/or enforcement cooperation. It merely establishes certain Federal health and safety standards for all coal mines beyond a certain size, authorizes the promulgation of other standards by the Mine Safety and Health Administration, and specifies Federal enforcement procedures.

\section{STATE AGENCIES}

The large number of state agencies and the variety of their responsibilities make detailed analysis difficult. However, the EH\&S activities in which most states engage can be grouped into nine functional categories, as illustrated in Exhibit 9.

LOCAL AGENCIES

Local energy and environmental activities generally involve EH\&S issues directly related to the surrounding community. Municipal or county ordinances restricting open burning, waste disposal, and water usage often predate state controls. In most 


\begin{tabular}{|c|c|c|}
\hline FUNCTION & DEFINITION & RESPONSIBLE AGENCY \\
\hline $\begin{array}{l}\text { Energy } \\
\text { Allocation/Coordination }\end{array}$ & $\begin{array}{l}\text { Administer state fuel allocation and related pro- } \\
\text { grams; coordinate state agency energy manage- } \\
\text { ment and use policies; advise Governor on timely } \\
\text { energy issues. }\end{array}$ & $\begin{array}{l}\text { Organization in state executive branch (e.g., } \\
\text { energy office, energy council). }\end{array}$ \\
\hline Environmental Protection & $\begin{array}{l}\text { Promulgate and enforce state and/or Federal envi- } \\
\text { ronmental laws, standards, and regulations. }\end{array}$ & $\begin{array}{l}\text { State department of natural resources or environ- } \\
\text { mental protection (or media-specific agency, e.g., } \\
\text { air quality control board). }\end{array}$ \\
\hline Planning & $\begin{array}{l}\text { Develop and administer plans for economic devel- } \\
\text { ment, land use planning, etc. (May also implement } \\
\text { the Federal Coastal Zone Management Act). }\end{array}$ & $\begin{array}{l}\text { Planning, coordination, or budget office within } \\
\text { the state executive branch. }\end{array}$ \\
\hline Facility Siting/Operation & $\begin{array}{l}\text { Approve or reject siting of energy-producing facili- } \\
\text { ties (e.g., power plants) and determine utility rate } \\
\text { structures. }\end{array}$ & $\begin{array}{l}\text { Public service, utility commission (or power sit- } \\
\text { ing commission, for facility siting). }\end{array}$ \\
\hline $\begin{array}{l}\text { Occupational Safety and } \\
\text { Health Protection }\end{array}$ & $\begin{array}{l}\text { Promulgate and enforce state occupational safety } \\
\text { and health standards and regulations. }\end{array}$ & $\begin{array}{l}\text { Department of labor land sometimes a mine } \\
\text { safety bureau). }\end{array}$ \\
\hline Fish and Game Enhancement & $\begin{array}{l}\text { Enhance and propagate fish and wildlife; enforce } \\
\text { hunting and fishing laws. }\end{array}$ & $\begin{array}{l}\text { Fish and/or game commissions or departments of } \\
\text { conservation or natural resources. }\end{array}$ \\
\hline Extension Services & $\begin{array}{l}\text { Provide technical education and assistance in agri- } \\
\text { cultural and other areas (such as consumption). }\end{array}$ & $\begin{array}{l}\text { County extension services (supported by state } \\
\text { and Federal funding and expertise). }\end{array}$ \\
\hline Agricultural Regulation & $\begin{array}{l}\text { Promulgate and enforce state agricultural regula- } \\
\text { tions to safeguard consumers and control plant } \\
\text { and animal disease; aid in marketing agricultural } \\
\text { products and improving farm life quality. }\end{array}$ & Department of agriculture \\
\hline Research & $\begin{array}{l}\text { Conduct and/or fund and monitor research in } \\
\text { energy- and environment-related areas. }\end{array}$ & $\begin{array}{l}\text { Technical advisory committees or state university } \\
\text { affiliated organizations (funded by Federal, state, } \\
\text { or private sources). }\end{array}$ \\
\hline Other & $\begin{array}{l}\text { Fulfill advisory, oversight, and other roles related } \\
\text { to energy/environmental issues. }\end{array}$ & $\begin{array}{l}\text { State or citizens advisory boards, councils, } \\
\text { commissions, etc. }\end{array}$ \\
\hline
\end{tabular}

\section{EXHIBIT 9}

STATE ORGANIZATIONS

ENERGY/ENVIRONMENTAL FUNCTIONS 
jurisdictions, local ordinances are now consistent with state laws, and enforcement is coordinated between local boards and state agencies.

planning and zoning regulations are the two local energy/ environmental functions which remain relatively independent of Federal and state authority. Planning functions include long-range local planning, usually performed by county planning commissions via "comprehensive plans" to help municipalities and unincorporated areas provide for future community services, resource conservation, and overall economic development. Zoning activities involve the regulation of land use by type of activity or building structure, and are usually carried out by municipal boards or county commissions. Local coordination with state planning bodies is common, but not always mandatory. The fact that many state laws permit zoning in unincorporated areas only after the adoption of some formal, areawide plan illustrates the need for close coordination between state and local agencies. 
THIS PAGE

\section{WAS INTENTIONALLY LEFT BLANK}


SECTION VIII
REGIONAL AND INIERSTATE ORGANIZATIONS

.

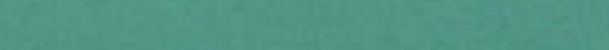
-

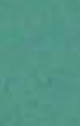

(5) .

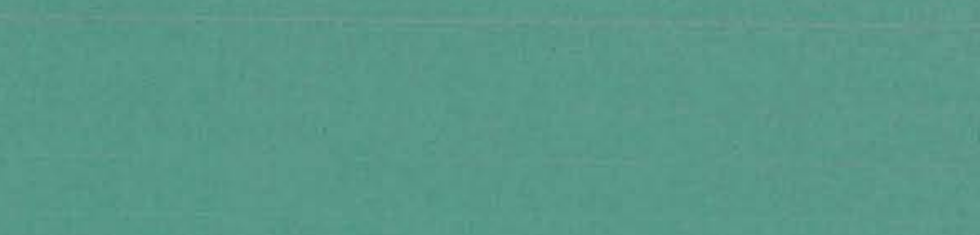




\section{SECTION VIII}

\section{REĠIONAL AND IN'L'E'RS'L'A'L'E 'UKGANTZATIONS}

Most of the regional and interstate organizations included in this section were formed by Presidential Executive Order or Federalinterstate compact. The majority are operated by relatively small administrative and professional staffs which usually support appointed representatives of member states.

The organizations generally aim to promote environmentally sound planning, development, and management of regional resources. Many publish newsletters and disseminate information to further public awareness of their activities. Those with larger budgets conduct their own research, studies, and demonstration projects. The primary responsibilities of the organizations fit into one of two categories: water management, and general regional economic development and resources management. Exhibit 10 displays summary information on selected regional and interstate organizations.

\section{WATER MANAGEMENT}

Watershed and River Basin Management

Many regional organizations have been created to resolve conflicts concerning the allocation of water resources. In the western states, where water availability has always been limited, many interstate compacts and agreements have been instituted to allocate water among member states. This issue can have an important impact on the 


\begin{tabular}{|c|c|c|c|}
\hline ORGANIZATION & $\begin{array}{l}\text { DATE } \\
\text { EST. }\end{array}$ & $\begin{array}{l}\text { ENERGY-RELATED } \\
\text { ENVIRONMENTAL RESPONSIBILITIES }\end{array}$ & STATE REPRESENTATION \\
\hline $\begin{array}{l}\text { WATER MANAGEMENT } \\
\text { RIVER BASIN MANAGEMENT }\end{array}$ & & & \\
\hline $\begin{array}{l}\text { Delaware River Basin } \\
\text { Commission* }\end{array}$ & 1961 & Plan, develop, manage, protect basin's water resources. & NJ, DE, PA, NY \\
\hline Great Lakes Commission & 1955 & $\begin{array}{l}\text { Study regional water resource matters, protect water - } \\
\text { quality. }\end{array}$ & MI, IL, IN, OH, NY, PA, WI, MN \\
\hline Great Lakes Basin Commission" & 1967 & $\begin{array}{l}\text { Act as the principal coordinating agent for Federal, } \\
\text { state, and local agencies for water and land-related } \\
\text { resources in the region. }\end{array}$ & MI, IL, IN, OH, NY, PA, WI, MN \\
\hline $\begin{array}{l}\text { Interstate Commission on } \\
\text { Potomac River Basin }\end{array}$ & 1940 & $\begin{array}{l}\text { Interpret and collect data on condition of streams in } \\
\text { Potomac watershed; disseminate information; } \\
\text { cooperate in studies. }\end{array}$ & MD, PA, DC, VA, WV \\
\hline $\begin{array}{l}\text { Missouri River Basin } \\
\text { Commission" }\end{array}$ & 1972 & $\begin{array}{l}\text { Conduct and coordinate water and rcloted lend resources } \\
\text { planning: with Federal agencies. }\end{array}$ & $\begin{array}{l}\text { CO, IA, KS, MN, MO, MT, } \\
\text { NE, ND, SD, WY }\end{array}$ \\
\hline $\begin{array}{l}\text { New England River Basin } \\
\text { Commission* }\end{array}$ & 1967 & $\begin{array}{l}\text { Promote the optimum use of water and related land } \\
\text { through coordinated Federal, state, and regional planning: }\end{array}$ & NY, MS, CT, ME, NH, RI, VT \\
\hline Ohio River Basin Commission" & 1970. & $\begin{array}{l}\text { Act as principal coordinating agency for Federal, state, } \\
\text { interstate, local, and non-governmental development } \\
\text { plans for water and land-related resources in region. }\end{array}$ & $\begin{array}{l}\text { OH, IL, IN, KY, MD, NY, NC, } \\
\text { PA, TN, VA, WV }\end{array}$ \\
\hline $\begin{array}{l}\text { Pạcific Northwest River } \\
\text { Basins Commision* }\end{array}$ & 1967 & Promote optimum use of water and related land resources. & WA, OR, MN, WY, ID \\
\hline $\begin{array}{l}\text { Susquehanna River } \\
\text { Basin Commission }\end{array}$ & 1970 & Conserve and develop water and water-related resources. & MD, PA, NY \\
\hline $\begin{array}{l}\text { Upper Colorado River } \\
\text { Commission }\end{array}$ & 1949 & $\begin{array}{l}\text { Carry out the provisions of the interstate compact; } \\
\text { control water distribution to five states. }\end{array}$ & CO, WY, NM, UT, AZ \\
\hline $\begin{array}{l}\text { Upper Mississippi River } \\
\text { Basin Commission" }\end{array}$ & 1972 & $\begin{array}{l}\text { Conduct ecological studies on impact of development } \\
\text { on region. }\end{array}$ & IL, IA, MN, MO, ND, SD, WI \\
\hline \multicolumn{4}{|l|}{$\begin{array}{l}\text { OTHER WATER } \\
\text { QUALITY MANAGEMENT }\end{array}$} \\
\hline $\begin{array}{l}\text { Interstate Sanitation } \\
\text { Commission }\end{array}$ & 1936 & Conduct studies on water and air pollution abatement. & NY, NJ, CT \\
\hline $\begin{array}{l}\text { Minnesota-Wisconsin } \\
\text { Boundary Commission }\end{array}$ & 1965 & $\begin{array}{l}\text { Conduct studies, develop recommendations, coordinate } \\
\text { planning for protection, use and development of lands, } \\
\text { river valleys, water; principally St. Croix and Mississippi } \\
\text { Rivers. }\end{array}$ & MN, WI \\
\hline Mississippi River Commission & 1879 & Serve as advisory body to the Corps of Engineers. & LA, MS, TN, KY, MO, IL, AR \\
\hline $\begin{array}{l}\text { New England Interstate } \\
\text { Water Pollution } \\
\text { Controi Commission }\end{array}$ & 1947 & $\begin{array}{l}\text { Coordinate work of member states in control of pollu- } \\
\text { tion of interstate waters, water quality standards: } \\
\text { train waste treatment operators. }\end{array}$ & NY, CT, MS, VT, ME, NH, RI \\
\hline $\begin{array}{l}\text { Ohio River Valley } \\
\text { Sanitation Commission }\end{array}$ & 1948 & Promote water pollution control. & IL, IN, KY, NY, OH, PA, VA, WV \\
\hline \multicolumn{4}{|l|}{ FISHERIES MANAGEMENT } \\
\hline $\begin{array}{l}\text { Atlantic States Marine } \\
\text { Fisheries Commission }\end{array}$ & 1942 & $\begin{array}{l}\text { Promote better utilization of fisheries-marine, shell, and } \\
\text { anadromous; prevent physical waste; promote and pro- } \\
\text { 'tect fisheries. }\end{array}$ & $\begin{array}{l}\text { ME, MA, CT, NH, NY, NJ, NC, } \\
\text { SC, VA, GA, FL, PA, MD, RI, DE }\end{array}$ \\
\hline $\begin{array}{l}\text { Gulf States Marine } \\
\text { Fisheries Commission }\end{array}$ & 1949 & Promote proper utilization of Gulf Cuast fisherles. & AL, FL, LA, MS, TX \\
\hline $\begin{array}{l}\text { Pacific Marine Fisheries } \\
\text { Commission }\end{array}$ & 1947 & $\begin{array}{l}\text { Promote better utilization of fisheries, prevent physical } \\
\text { waste in Pacific and, tributary streams. }\end{array}$ & AK, CA, ID, OR, WA \\
\hline
\end{tabular}

"Operates in conjunction with the Water Resources Council. EXHIBIT 10

REGIONAL AND INTERSTATE ORGANIZATIONS

ENERGY/ENVIRONMENTAL FUNCTIONS 


\begin{tabular}{|c|c|c|c|}
\hline ORGANIZATION & $\begin{array}{l}\text { DATE } \\
\text { EST. }\end{array}$ & $\begin{array}{l}\text { ENERGY-RELATED } \\
\text { ENVIRONMENTAL RESPONSIBILITIES }\end{array}$ & STATE REPRESENTATION \\
\hline $\begin{array}{l}\text { ECONOMIC DEVELOPMENT } \\
\text { AND } \\
\text { RESOURCE MANAGEMENT }\end{array}$ & & $\cdot$ & \\
\hline Regional Commissions: & & $\begin{array}{l}\text { Promote the economic, social, and physical develop- } \\
\text { ment of the region; provide a framework for joint } \\
\text { 'Federal/state programs. }\end{array}$ & \\
\hline $\begin{array}{l}\text {-Appalachian Regional } \\
\text { Commission }\end{array}$ & 1965 & & $\begin{array}{l}A L, G A, K Y, M D, M S, N Y, N C, \\
O H, P A, S C, V A, W V\end{array}$ \\
\hline $\begin{array}{l}\text {-Coastal Plains Regional } \\
\text { Commission }\end{array}$ & 1965 & + & GA, NC, SC \\
\hline $\begin{array}{l}\text {-Four Corners Regional } \\
\text { Commission }\end{array}$ & 1965 & & $A Z, C O, N M, V T$ \\
\hline -Ozarks Regional Commission & 1966 & & AK, KS, MO, OK \\
\hline $\begin{array}{l}\text {-Pacific Northwest Regional } \\
\text { Commission }\end{array}$ & 1972 & & ID, OR, WA \\
\hline $\begin{array}{l}\text {-Southwest Border Regional } \\
\text { Commission }\end{array}$ & 1977 & & $A Z, C A, N M, T X$ \\
\hline $\begin{array}{l}\text {-Upper Great Lakes Regional } \\
\text { Commission }\end{array}$ & 1965 & . & MI, MN, WI \\
\hline $\begin{array}{l}\text { Northern Great Plains } \\
\text { Resources Program }\end{array}$ & 1971 & $\begin{array}{l}\text { Provide a focal point for collecting, coordinating, and } \\
\text { communicating information on natural resources and } \\
\text { on the relationship of human activities to these resources. }\end{array}$ & MT, NE, ND, SD, WY \\
\hline $\begin{array}{l}\text { Western Governors' Regional } \\
\text { Energy Policy Office }\end{array}$ & 1975 & $\begin{array}{l}\text { Provide a focal point for state decisions regarding energy } \\
\text { development and environmental protection; coordinate } \\
\text { with Federal agencies responsible for energy decisions.: }\end{array}$ & $\begin{array}{l}\text { AZ, CO, MT, ND, NE, NM, NV, } \\
\text { SD, UT, WY }\end{array}$ \\
\hline
\end{tabular}


development of energy resources and on agriculture, traditionally the largest water-consuming sector of American business.

Water quality is often a more immediate concern than water sup-

ply. Regional organizations conduct comprehensive planning. They have evolved under the aegis of the Water Resources Council, or were created by Federal-interstate compact. Their major purposes are to monitor, influence, and, when possible, direct regional development to minimize air and water pollution. Water supply and water-related land use are other priority concerns. Activities may vary from recreational demonstration projects to water quality studies and standards development. Other Water Management

Sanitation and water pollution control commissions also have regional water responsibilities, but specialize in waste treatment and monitoring. Boundary commissions resolve water management issues between two-state, as opposed to multi-state, jurisdictions. Fisheries Management

There are many regional organizations which address fishery resource management. Most have limited authority and act only in an advisory capacity. Several regional marine fisheries commissions have evolved from compacts among coastal states. Some have been delegated regulatory functions by their parent states. Their main function is to enhance and protect commercially valuable marine fish and shellfish resources, a major concern in energy technology development, and one which particularly affects energy facility siting. 
GENERAL ECONOMIC DEVELOPMENT AND RESOURCE MANAGEMENT

Regional Commissions

Not a11 regional commissions have water resources as their central focus. Eight Regional Commissions, composed of Federal/state partnerships, were established pursuant to the Public Works and Economic Development Act of 1965. A ninth, The Appalachian Regional Commission, was established in 1965 under the authority of the Appalachian Regional Development Act. The Commissions are designed to promote orderly economic growth, including the development and management of energy, water, and natural resources.

The Northern Great Plains Resources Program

Another example of a regional, Federal/state partnership is the Northern Great Plains Resources Program. This program was organized in 1971 as a joint effort by three Federal agencies (EPA, DOI, and USDA) and the state governments of Montana, Nebraska, North Dakota, South Dakota, and Wyoming. The Great Plains Program provides a focal .point for the collection, coordination, and communication of information about natural resources in the Northern Great Plains, and about the relationship of human activities to these resources. Western Governors' Regional Energy Policy. Office

Another regional organization which is heavily involved in decisions regarding energy development and environmental protection is the Western Governors' Regional Energy Policy Office. This Office was developed by the Federation of Rocky Mountain States. It is a private, non-profit corporation based in Denver, Colorado, and 
directed by the governors of Colorado, New Mexico, Montana, Ut ah and Wyoming. The Office also represents the governors of Arizona, Nebraska, Nevada, North Dakota and South Dakota. It was created to identify and act upon mutual concerns and to serve as a mechanism for cooperation with the various Federal agencies involved in energy decisions. 
ASSOCIATIONS AND INTEREST GROUPS

\section{SECTION IX}

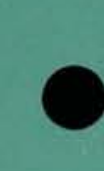
$\infty$

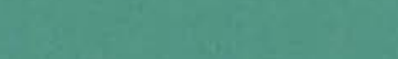
ASsociA .

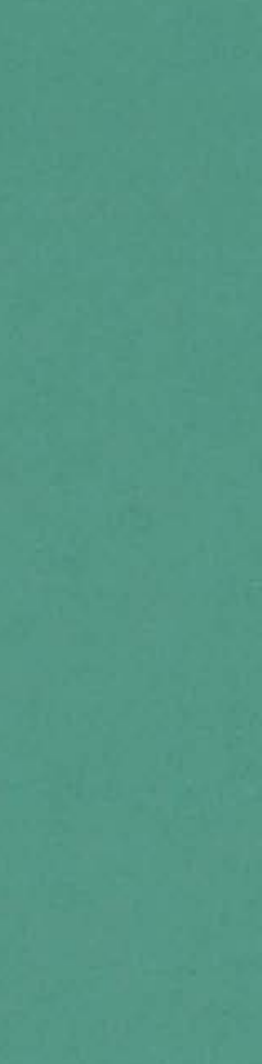
列 列 (n) thelife $4 x^{3}$ Dt (2.ine

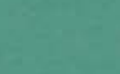


SECTION IX

ASSOCIATIONS AND INTEREST GROUPS

Thousands of associations and interest groups engage in energyrelated environmental activities. Their origins, funding, membership characteristics, objectives, and scopes vary widely. Whether they are primarily or peripherally involved with environmental issues, their tax status depends on the extent of their involvement in the legislative process.

The many differences among associations and interest groups make categorization difficult. Generalization tends to blur the distinctions between some groups and to understate the scope of others. Nevertheless, for the purposes of this document, they can generally be classified by type of membership, by function, and by tax status. Exhibit 11 illustrates membership and functional categorizations for

a few associations and interest groups.

MEMBERSHIP CHARACTERISTICS

There are four types of membership classifications for associations and interest groups.

1. Citizens' groups, such as the National Wildlife Federation and the Energy Action Committee, are voluntary organizations of individuals who join to support group objectives.

2. Industry and trade associations, such as the American Petroleum Institute, the American Gas Association, and the Edison Electric Institute, are formed to promote common industrial or commercial interests. 


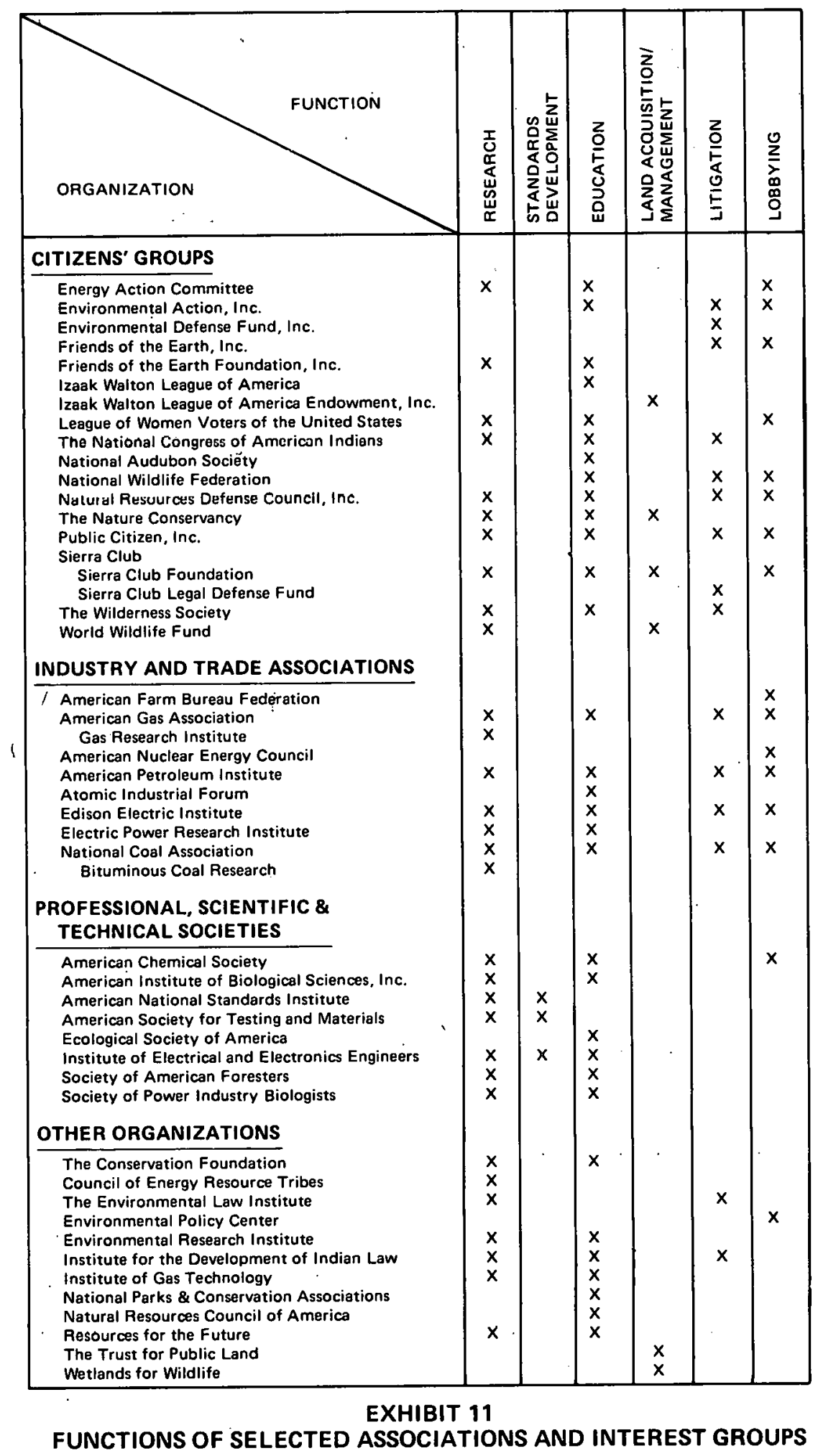


3. Professional, scientific and technical societies include the American Chemical Society and the Institute of Electrical and Electronics Engineers, Inc., whose members are interested in problems common to their professional backgrounds.

4. Other types of associations range from the Institute of Gas Technology, an educational and research organization sponsored by natural gas companies but affiliated with the Illinois Institute of Technology, to the Institute for the Development of Indian Law (IDIL), which conducts litigation on behalf of Indian rights.

The IDIL and the National Congress of American Indians, an association of tribes and individuals, represent the interests of American Indians. Over 50 million acres of 1 and in the contiguous United States and 40 million acres of land in Alaska are held by the Federal Government in trust for Indians, Aleuts, and Eskimos. An additional 2.1 million acres of Government-owned land is administered by the Bureau of Indian Affairs for the use and benefit of Indians. The major income from this land comes from mineral rentals, bonuses, agricultural production, and tourism. Principal energy resources include oil and gas, uranium, and coal. For example, oil production on the lands of only two Indian tribes, the Navajos of New Mexico and the Osages in Oklahoma, totaled over 75 million barrels, or 2.5 percent of 1977 U.S. production. Estimated coal reserves on the lands of the Crow tribe and the Northern Cheyennes, both in Montana, are on the order of 13-20 billion tons. Furthermore, some of this coal is of the highly attractive low sulfur variety.* These coal

\footnotetext{
*Source:" Bureau of Indian Affairs, U.S. Geological Survey.
} 
reserves remain largely undeveloped, however, because the tribes which control them do not consider that further development presently serves their best interests.

The Council of Energy Resource Tribes (CERT) was formed in 1975 by 25 tribes in ten states. CERT members own about 40 percent of total U.S. uranium reserves, approximately 11 percent of the nation's coal reserves, about 4 percent of the country's oil and natural gas reserves, and large oil shale and geothermal resources.* Clearly, CERT will influence the direction of U.S. energy development. "The purpose of CERT is to promote the general welfare of the energy resource tribes and their people through the prudent management of their energy resources."* Environmental protection is a primary concern of CERT.

Under Federal law, Indian tribes are recognized as distinct political entities, possessing limited elements of sovereignty. Tribal autonomy includes "the power to adopt and operate under a form of government of the tribe's choosing, to define conditions of tribal membership, to regulate domestic relations of members, to prescribe rules of inheritance, to levy taxes, to regulate property within the jurisdiction of the tribe, to control the conduct of members by tribal legislation, to administer justice and provide for the punishment of offenses committed on the reservation" (emphasis added)**. Tribal government and interests are the responsibility of a governor or a council.

*Source: Council of Energy Resource Tribes, unpublished descriptive material.

**Felix S. Cohen, Handbook of Federal Indian Law, GPO, Washington, D.C. $(1942)$, p. 123 . 
Federal agencies responsible for Indian affairs include the Bureau of Indian Affairs in the Department of Interior, the Indian Claims Commission, and the Four Corners Regional Commission. Indian tribes are also unique in that they are represented in certain legal matters by the Land and Natural Resources Division of the U.S. Department of Justice.

ORGANIZATIONAL FUNCTIONS

Energy/environment-related associations and interest groups can be described by the types of activities in which they engage, i.e., a functional classification. The functions considered herein include:

1. research,

2. standards development,

3. education,

4. land acquisition and/or management,

5. litigation, and

6. lobbying.

Environmental, health, and safety (EH\&S) research is conducted by a wide variety of associations and interest groups, each pursuing its own specific objectives. This research may involve large resource expenditures, as exemplified by the Electric Power Research Institute (EPRI) and its integrated program to improve electric power production, distribution, and utilization. EPRI's Energy Analysis and Environment Division addresses EH\&S issues. EH\&S research is also pursued by much smaller organizations, such as the Environmental 
Research Institute, which conducts research on the cause-and-effect relationships of humans and their environment.

Numerous professional societies, associations, and other private, non-profit organizations are involved in developing and adopting voluntary standards (e.g., for materials, equipment, engineering procedures, etc.) with EH\&S ramifications. Although such standards are not legally binding, they do provide useful input to Federal, state and local bodies which are responsible for establishing EH\&S standards. Three organizations which illustrate this function are the Institute of Electrical and Electronics Engineers, The American Society for Testing and Materials, and the American National Standards Institute.

A major function of most associations and interest groups is the collection, interpretation and dissemination of data for educational purposes. Activities here include teaching and training, publishing and communicating by other media, public speaking, participating on advisory committees, and conducting workshops, meetings, "symposia, etc. Among citizens' groups, the Sierra Club and the National Wildlife Federation are two of the most influential. Well-known industry and trade associations include the American Petroleum Institute, the American Gás Association, and the Electric Power Research Institute. Educational activities are also carried out by professional associations such as the American Chemical Society, and other types of organizations, such as the Conservation Foundation and the Natural Resources Council of America. 
Some interest groups acquire and manage land. The Izaak Walton League of America Endowment, Inc., for example, buys land for later resale to government agencies or other organizations which agree to preserve its natural state. The Nature Conservancy cooperates with colleges, universities, and conservation organizations to acquire lands for scientific and educational purposes. The Sierra Club Foundation, a public, nonprofit, tax-deductible foundation, finances land acquisition and preservation projects. The World Wildlife Fund is a private, tax-exempt international organization which makes grants for land acquisition, habitat protection, and scientific ecological research in all parts of the world.

Several organizations, including the Environmental Defense Fund, Inc., and the Sierra Club Legal Defense Fund, are chiefly devoted to environmental litigation. Others, such as The Wilderness Society and the National Coal Association, include litigation among a broader program of activities. In recent years, Federal laws have explicitly provided for environmental "citizen suits in Federal courts, either against private polluters or government officials or agencies for alleged non-enforcement of or non-compliance with laws, regulations, or standards." Many suits have questioned the siting of energy facilities. Other questions may be raised, as in the suit brought by Friends of the Earth, the Wilderness Society, and the Environmental Defense Fund against the Department of the Interior (DOI). That suit challenged the adequacy of the draft Environmental Impact Statement (EIS), as required by the National Environmental Policy Act, for the 
Trans-Alaska pipeline. The litigation resulted in a comprehensive revision of the EIS by DOI.

Certain environmental, industrial, and other organizations with EH\&S interests engage in lobbying activities. The nature of these efforts to influence legislative and administrative decisionmaking processes varies widely. As input to the legislative process, organizations might provide research data, fact sheets, or testimony. Whatever technique is used, the object is to influence the final version of a law or regulation. Specific examples include testimony from the Sierra Club and the Natural Resources Defense Council, Inc., before the Senate Committee on Energy and Natural Resources concerning the Outer Continental Shelf Lands Act of 1977. Prepared statements from the Wilderness Society and Friends of the Earth concerning the Omnibus Wilderness Hearings before the House Committee on Interior and Insular Affairs in 1976 are another. For administrative decisions, lobbying activities may be in the form of comments on proposed regulations or petitions for rulemaking. In the latter case, petitions may be filed with agencies to establish a particular regulation where none exists.

\section{TAX STATUS}

A third criterion for classification of associations and interest groups is their tax status under the U.S. Internal Revenue Service (IRS) Code. Section 501(c)(3) provides a tax-deductible status for organizations, such as the Sierra Club Foundation, which 
engage in scientific or educational pursuits. However, IRS limits the amount which tax-deductible organizations can spend to influence the legislative process. For organizations qualifying under Section 501 (c)(6) as tax-exempt trade associations, there is no financial limit set upon lobbying. One such organization is the National Coal Association. A third type of organization is exemplified by the American Nuclear Energy Council, which is predominantly a lobbying group, but is not tax-exempt. The number of groups and associations involved in lobbying has grown significantly in recent years, reflecting the steady growth in environmental and energy-related legislation. 
THIS PAGE

\section{WAS INTENTIONALLY LEFT BLANK}




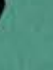

\author{
SECTION $\mathrm{X}$
TIONAL ORGANIZATIONS \\ SECTION $\mathrm{X}$
INTERNATIONAL ORGANIZATIONS \\ SECTION $\mathrm{X}$
INTERNATIONAL ORGANIZATIONS

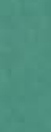
$y^{3}$ it:

nuts thes

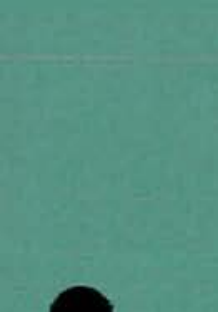

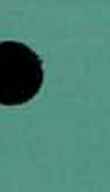

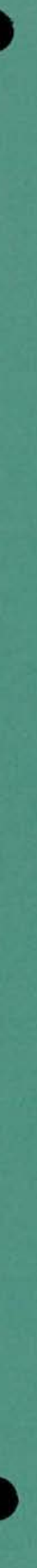




\section{SECTION $\mathrm{X}$}

\section{INTERNATIONAL ORGANIZATIONS}

International organizations can be classified into three groups: United Nations agencies and programs, other intergovernmental organizations, and nongovernmental organizations. Representatives of each category are discussed below.

UNITED NATIONS AGENCIES AND PROGRAMS

The United Nations (UN) sponsors a number of programs concerned with energy-environmental problems. The UN Environment Programme (UNEP) bears the lead responsibility for advancing UN environmental goals. Energy-related environmental impacts are among its priority concerns.

The UNEP was created in Stockholm in 1972, during the first UN Conference on Human Environment. The 112 nations that were represented drew up a "Declaration on the Human Environment," which makes 109 specific recommendations to national governments, international organizations, and UN agencies for dealing with existing and anticipated world environmental problems. The Declaration has since been adopted by the UN General Assembly, which created UNEP to promote international environmental cooperation. UNEP reviews the world environmental situation to insure that nations adequately consider significant environmental problems. It also promotes the acquisition, assessment, and exchange of environmental knowledge. 
In addition to UNEP, there are two other UN agencies with broad interests in environmental quality. These are the Food and Agricultural Organization (FAO) and the United Nations Educational, Scientific and Cultural Organization. Other UN divisions approach energy-related EH\&S issues from a more specific point of view. Air quality issues are addressed by the World Health Organization (WHO) and the World Meteorological Organization (WMO), buth of which conduct major air pollution monitoring programs worldwide.' The Resource and Transport Division (RTD) of the UN Secretariat has an interest in mineral and energy resource development and in water quality and pollution control. RTD has a special interest in pollution of the sea from subsea operations, such as oil and natural gas drilling and production. Prompted by a request from the U.S. President, UN Intergovernmental Maritime Consultative Organization committees held specially scheduled sessions on the subject of oil spills in 1977 and 1978. Another UN agency, the International Atomic Energy Agency, cooperates with FAO in monitoring radiation contamination of food, and with WMO in monitoring isotopes in precipitation. The International Labor Organization and WHO are active in the field of occupational safety and health. The World Bank concerns itself with energy and environmental issues raised by its economic assistance programs. These and other UN agencies and programs which address energy-related EH\&S issues, are listed in Exhibit 12. 


\begin{tabular}{|c|c|c|c|}
\hline ORGANIZATION & $\begin{array}{l}\text { DATE } \\
\text { EST. }\end{array}$ & $\begin{array}{l}\text { ENERGY-RELATED } \\
\text { ENVIRONMENTAL RESPONSIBILITIES }\end{array}$ & MEMBERSHIP \\
\hline UN Programs & & & $\cdot$ \\
\hline $\begin{array}{l}\text {-UN Environment Programme } \\
\text { (UNEP) }\end{array}$ & 1972 & $\begin{array}{l}\text { Promote international cooperation in the environmental } \\
\text { field; review world environmental situation to ensure ade- } \\
\text { quate consideration of problems; promote acquisition } \\
\text { and exchange of environmental knowledge. }\end{array}$ & 112 UN members \\
\hline -UN General Assembly & 1945 & $\begin{array}{l}\text { Conduct research on the peaceful uses of the sea-bed and } \\
\text { ocean floor, effects of atomic radiation. }\end{array}$ & All UN members \\
\hline -UN Secretariat & 1945 & $\begin{array}{l}\text { Study effects of industrialization, urbanization, noise, } \\
\text { air and water pollution. }\end{array}$ & Administrative office \\
\hline $\begin{array}{l}\text {-UN Economic and Social } \\
\text { Council (ECOSOC) }\end{array}$ & 1945 & $\begin{array}{l}\text { Study economic, environmental, and health aspects of } \\
\text { various international issues. }\end{array}$ & 54 UN members \\
\hline $\begin{array}{l}\text {-UN Development Programme } \\
\text { (UNDP) }\end{array}$ & 1965 & $\begin{array}{l}\text { Support projects to prevent detrimental environmental } \\
\text { consequences of development (land and water quality } \\
\text { emphasis). }\end{array}$ & $\begin{array}{l}\text { Executing agencies: UN, ILO, } \\
\text { FAO, UNESCO, ICAO, WHO, } \\
\text { IBRD, ITU, WMO, IAEA, UPU, } \\
\text { IMCO, UNCAD, UNIDO, IBD, } \\
\text { ADB, UNCTAD }\end{array}$ \\
\hline $\begin{array}{l}\text {-UN Research Institute for } \\
\text { Social Development (UNRISD) }\end{array}$ & 1964 & $\begin{array}{l}\text { Conduct research on regional planning problems, environ- } \\
\text { mental effects of social development. }\end{array}$ & $\begin{array}{l}\text { France, India, Sweden, Nigeria, } \\
\text { Yugoslavia, Mexico, U.S. }\end{array}$ \\
\hline $\begin{array}{l}\text {-UN Industrial Development } \\
\text { Organization (UNIDO) }\end{array}$ & 1967 & $\begin{array}{l}\text { Conduct research on environmental problems of } \\
\text { industrialization. }\end{array}$ & 45 UN members \\
\hline $\begin{array}{l}\text {-UN Institute for Training and } \\
\text { Research (UNITAR) }\end{array}$ & 1965 & $\begin{array}{l}\text { Conduct research on the atomic safeguards-system } \\
\text { and technology transfer. }\end{array}$ & 24 UN members \\
\hline UN Sponsored Programs & & & - \\
\hline $\begin{array}{l}\text {-Committee for the Coordina- } \\
\text { tion of Investigations of the } \\
\text { Lower Mokong Basin }\end{array}$ & 1957 & $\begin{array}{l}\text { Seek comprehensive development of water and other } \\
\text { resources. }\end{array}$ & $\begin{array}{l}\text { Khmer Republic, Laos, Thailand, } \\
\text { Democratic Republic of Vietnam } \\
\text { with } 25 \text { countries acting in } \\
\text { cooperation }\end{array}$ \\
\hline $\begin{array}{l}\text {-Committee for Coordination } \\
\text { of Joint Prospecting for Min- } \\
\text { eral Resources in Asian Off- } \\
\text { shore Areas }\end{array}$ & 1966 & $\begin{array}{l}\text { Conduct geophysical surveys of marine shelves and } \\
\text { investigations in coastal, near-shore areas. }\end{array}$ & $\begin{array}{l}\text { Japan, Indonesia, Taiwan, Thai- } \\
\text { land, Republic of Korea, Malaysia, } \\
\text { Philippines, Khmer Republic } \\
\end{array}$ \\
\hline UN Specialized Agencies & & & \\
\hline $\begin{array}{l}\text {-International Atomic Energy } \\
\text { Agency (IAEA) }\end{array}$ & 1957 & $\begin{array}{l}\text { Conduct research and regulations on radioactive } \\
\text { waste disposal, health and safety standards. }\end{array}$ & 34 UN members \\
\hline $\begin{array}{l}\text {-International Labor } \\
\text { Organization (ILO) }\end{array}$ & 1919 & Protect workers' health and environmental safety. & $\begin{array}{l}28 \text { government members, } 14 \mathrm{em} \text { - } \\
\text { ployees' members, } 14 \text { workers' } \\
\text { members, } 10 \text { member's from UN } \\
\text { states of industrial importance }\end{array}$ \\
\hline $\begin{array}{l}\text {-Food and Agriculture } \\
\text { Organization (FAO) }\end{array}$ & 1945 & $\begin{array}{l}\text { Conduct research on forestry, fisheries, wildlife } \\
\text { management. }\end{array}$ & 42 UN members \\
\hline $\begin{array}{l}\text {-UN Educational, Scientific, } \\
\text { and Cultural Organization } \\
\text { (UNESCO) }\end{array}$ & 1945 & $\begin{array}{l}\text { Develop international cooperation in the natural sci- } \\
\text { ences by organizing meetings, promoting information ex- } \\
\text { change, and assisting activities of international scientific } \\
\text { organizations for a wide range of environmental issues. }\end{array}$ & All UN members. \\
\hline $\begin{array}{l}\text { - World Health Organization } \\
\text { (WHO) }\end{array}$ & 1948 & $\begin{array}{l}\text { Conduct research on health aspects of energy and } \\
\text { environment. }\end{array}$ & All UN members \\
\hline -World Bank Group & 1945 & $\begin{array}{l}\text { Review and evaluate all economic development projects } \\
\text { to ensure environmental protection (Office of Environ- } \\
\text { mental Affairs). }\end{array}$ & IBRD, IFC, IDA \\
\hline $\begin{array}{l}\text {-World Meteorological } \\
\text { Organization (WMO) }\end{array}$ & 1947 & $\begin{array}{l}\text { Conduct meteorological research on atmospheric compo- } \\
\text { sition, possible climatic changes. }\end{array}$ & Open to all UN members \\
\hline $\begin{array}{l}\text {-Inter- Governmental Maritime } \\
\text { Consultative Organization } \\
\text { (IMCO) }\end{array}$ & 1958 & $\begin{array}{l}\text { Prevent pollution of land, sea, or air by ships, vessels } \\
\text { and other marine equipment. }\end{array}$ & Open to all UN members \\
\hline
\end{tabular}


OTHER INTERGOVERNMENTAL ORGANIZATIONS

Numerous intergovernmental organizations (IGO) have been formed by international treaty or agreement to deal with energy-related EH\&S impacts. Most hold conferences, sponsor research, and disseminate information. They approach EH\&S issues from a regional, disciplinary, or resource-specific standpoint. Regional IGO's with special environmental units or programs include the Council of Europe, the North Atlantic Treaty Organization (NATO), the Organization for Economic Cooperation and Development (OECD), and the South Pacific Commission. NATO, for example, conducts programs involving air quality, solar and geothermal research, and water pollution. As with UN agencies, IGO's are also interested in more specific EH\&S issues. Nuclear energy issues are addressed by Euratom, the Inter-American Nuclear Energy Commission and the OECD Nuclear Energy Agency. Water quality and water resources management issues are addressed by an ad hoc Committee on Water Pollution in Inland Fresh Waters established by the Council of Europe. Other international commissions are dedicated to protecting specific rivers or international boundary waterways from pollution. A well-known IGO, the Organization of Petroleum Exporting Countries, supports the economic incerests of its members. A second IGO, the Regional Cooperation for Development, conducts programs on water resources development and investigates the peaceful uses of nuclear energy. An international developmentoriented lending institution such as the Inter-American Development 
Bank, which helps finance mining and electric power production projects, must take into account a great variety of EH\&S issues. Exhibit 13 illustrates a selected group of IGOs, their membership, and their energy-related EH\&S functions.

NONGOVERNMENTAL ORGANIZATIONS

International nongovernmental organizations (NGO) have much in common with their American counterparts. Their types of membership, their functions, and their diversity and numbers are remarkably similar. A representative sample is shown in Exhibit 14. NGO's include citizens' groups, such as Friends of the Earth International, and scientific and/or professional groups such as the International Radiation Protection Association (IRPA). Both of these groups are involved in the field of nuclear energy and radiation protection. The International Union for Conservation of Nature and Natural Resources (IUCN), the leading worldwide general conservation organization, is classified as an NGO, * although its membership is composed of national governments, government agencies, private organizations, and international groups from 93 countries. IUCN maintains working relationships with several UN agencies.

In addition to their membership characteristics, NGOs are functionally related to associations and interest groups "concerned with environmental EH\&S issues. Research on atmospheric pollution, geology, and mining is conducted by the International Union of *Source: Sierra Club, World Directory of Environmental Organizations, 1976. 


\begin{tabular}{|c|c|c|c|}
\hline ORGANIZATION & $\begin{array}{l}\text { DATE } \\
\text { EST. }\end{array}$ & $\begin{array}{l}\text { ENERGY.RELATED } \\
\text { ENVIRONMENTAL RESPONSIBILITES }\end{array}$ & MEMBERSHIP \\
\hline $\begin{array}{l}\text { Arab League Educational, Cul- } \\
\text { tural, and Scientific Organiza- } \\
\text { tion (ALESCO) }\end{array}$ & 1964 & $\begin{array}{l}\text { Finance scientific research, exchange information on sub- } \\
\text { soil water, marine resources, intand waters, conservation, } \\
\text { utilization of natural resources (Dept. of Natural Sciences) }\end{array}$ & 15 Arab states \\
\hline $\begin{array}{l}\text { Central Treaty Organization } \\
\text { (CENTO) }\end{array}$ & 1955 & $\begin{array}{l}\text { Study agricultural and mineral development, health im- } \\
\text { provement, scientific cooperation. }\end{array}$ & $\begin{array}{l}\text { Iran, Pakistan, Turkey, United } \\
\text { Kingdom }\end{array}$ \\
\hline $\begin{array}{l}\text { Commonwealth Agricultural } \\
\text { Bureaux }\end{array}$ & 1929 & $\begin{array}{l}\text { Provide comprehensive information servica for workers in } \\
\text { agricultural research, including animal health and forestry. }\end{array}$ & 26 countries \\
\hline $\begin{array}{l}\text { Commonwealth Committee on } \\
\text { Mineral Resources and Geology }\end{array}$ & 1948 & $\begin{array}{l}\text { Promote collaboration and exchange of mineral resources } \\
\text { information. }\end{array}$ & 21 Commonwealth countries \\
\hline $\begin{array}{l}\text { Commonwealth Scientific } \\
\text { Committee }\end{array}$ & 1946 & $\begin{array}{l}\text { Conduct mineral processing, fuel research, mineral re- } \\
\text { source and geology research. }\end{array}$ & 22 Commonwealth countries \\
\hline $\begin{array}{l}\text { Council for Mutual Economic } \\
\text { A ssistance (COMECON) }\end{array}$ & 1949 & $\begin{array}{l}\text { Foster economic and scientific cooperation-nuclear } \\
\text { energy, electric power, oil and gas, chemical industry, } \\
\text { agriculture. }\end{array}$ & $\begin{array}{l}\text { Albania, Bulgaria, Cuba, Czecho- } \\
\text { |slovakia, German Democratic } \\
\text { Republic, Hungary, Mongolia, } \\
\text { Poland, Romania, USSR } \\
\end{array}$ \\
\hline Council of Europe & 1949 & $\begin{array}{l}\text { Sponsor air pollution conferences and studies; conduct } \\
\text { research on water quality, public health. }\end{array}$ & 17 European nations and Turkey \\
\hline $\begin{array}{l}\text { Diplomatic Conference of Inter- } \\
\text { national Maritime Law }\end{array}$ & 1905 & $\begin{array}{l}\text { Seek uniformity in maritime legislation, water quality } \\
\text { protection. }\end{array}$ & $\begin{array}{l}\text { Open to all governments and } \\
\text { IGOs }\end{array}$ \\
\hline $\begin{array}{l}\text { East African Agriculture and } \\
\text { Forestry Resoarch }\end{array}$ & 1948 & $\begin{array}{l}\text { Act as scientific advisory body-conduct research in } \\
\text { forcstry, ontomology, soil fortility, wildlife. }\end{array}$ & Uganda, Kenya, Tanzania \\
\hline $\begin{array}{l}\text { East Africa Freshwater Fisherie } \\
\text { Research Organization }\end{array}$ & 1946 & $\begin{array}{l}\text { Evaluate lake resourcas; conduct limnologic and } \\
\text { pollution studies. }\end{array}$ & Uganda; Kenya, Tanzania \\
\hline $\begin{array}{l}\text { The European Community } \\
\text {-Euratom } \\
\text {-Committee for Scientific } \\
\text { and Technical Research }\end{array}$ & $\begin{array}{r}1957 \\
.1974\end{array}$ & $\begin{array}{l}\text { Assist members in nuclear growth; study nuclear safety; } \\
\text { inspect and regulate facilities. } \\
\text { Study environmentaf protection, biology and heafth } \\
\text { protection. }\end{array}$ & $\begin{array}{l}\text { BENELUX, Italy, Federal } \\
\text { Republic of Germany } \\
\text { BENELUX, Italy, France, } \\
\text { UK, Denmark, Ireland, Fed. } \\
\text { eral Republic of Germany }\end{array}$ \\
\hline $\begin{array}{l}\text { European Organization } \\
\text { for Nuclear Research }\end{array}$ & 1954 & $\begin{array}{l}\text { Participate in pure and fundamental sub-nuclear research, } \\
\text { including health and environmental effects. }\end{array}$ & 12 European countrias \\
\hline $\begin{array}{l}\text { General Fisheries Council for } \\
\text { the Mediterranean }\end{array}$ & 1952 & $\begin{array}{l}\text { Sponsor research, training, and data exchange on Mediter- } \\
\text { ranean fisheries problems, including water pollution. }\end{array}$ & 18 Mediterranean countries \\
\hline $\begin{array}{l}\text { Great Lakes Fishery } \\
\text { Commission }\end{array}$ & 1955 & $\begin{array}{l}\text { Conduct and coordinate research on fish stock } \\
\text { productivity, including water quality. }\end{array}$ & U.S., Canada \\
\hline Indo-Pacific Fisheries Council & 1955 & Conduct biological, hydrological research. & 18 Pacific countries \\
\hline $\begin{array}{l}\text { Inter-American Development } \\
\text { Bank (IDB) }\end{array}$ & 1959 & $\begin{array}{l}\text { Contribute to agricultural, mining, water supply, and } \\
\text { waste treatment projects. }\end{array}$ & 24 Western hemisphere countries \\
\hline $\begin{array}{l}\text { Inter-American Nuclear Energy } \\
\text { Commission }\end{array}$ & 1959 & $\begin{array}{l}\text { Assist member states in developing coordinated plans for } \\
\text { research and exchange of technical and scientific data on } \\
\text { peaceful uses of atomic energy. including health effects. }\end{array}$ & OAS states \\
\hline $\begin{array}{l}\text { International Boundary } \\
\text { and Water Commission }\end{array}$ & 1889 & Study waste treatment, water quality research. & U.S., Mexico \\
\hline $\begin{array}{l}\text { International Commission for } \\
\text { the Protection of the Moselle } \\
\text { Against Pollution }\end{array}$ & 1961 & $\begin{array}{l}\text { Seek to determine the nature, quantity, and origin of } \\
\text { pollution in the Moselle. }\end{array}$ & $\begin{array}{l}\text { France, Federal Republic of Ger- } \\
\text { many, Luxembourg. Netherlands, } \\
\text { Swiczertand }\end{array}$ \\
\hline $\begin{array}{l}\text { Internationsl Commission for } \\
\text { the Protection of the Rhine } \\
\text { Against Pollution }\end{array}$ & 1963 & $\begin{array}{l}\text { Conduct research to determine the nature, quantity. } \\
\text { and origin or pollution in the Rhine. }\end{array}$ & $\begin{array}{l}\text { France, Federal Republic of Ger- } \\
\text { many, Luxembourg, Netherlands, } \\
\text { Switzerland. }\end{array}$ \\
\hline $\begin{array}{l}\text { International Council for the } \\
\text { Explorstion of the Sea }\end{array}$ & 1902 & Sponsor marine pollution research. & 17 countries \\
\hline International Joint Commission & 1909 & Sponsor air and water pollution research. & U.S., Canada \\
\hline Inter-Parliamentary Union & 1889 & $\begin{array}{l}\text { Encourege perliaments to ensure conservation of natural } \\
\text { resources, protection of human health and environment. }\end{array}$ & 72 countries \\
\hline $\begin{array}{l}\text { Joint Institute for } \\
\text { Nuclear Research }\end{array}$ & 1956 & $\begin{array}{l}\text { Conduct scientific research on nuclear energy, including } \\
\text { environmental, health, and safety effects. }\end{array}$ & $\begin{array}{l}\text { People's Republic of China, USSR. } \\
\text { Poland, Bulgaria, Romania, Hun- } \\
\text { gary, German Democratic Repub- } \\
\text { lic, People's Republic of Korea, } \\
\text { Democratic Republic of Vietnam }\end{array}$ \\
\hline League of Arab States (LAS) & 1945 & $\begin{array}{l}\text { Sponsor research on the health effects of petroleum } \\
\text { technologies. }\end{array}$ & 18 Arab states \\
\hline $\begin{array}{l}\text { North Atlantic Treaty } \\
\text { Organizotion (NATO) }\end{array}$ & 1949 & 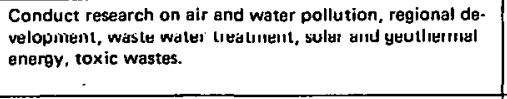 & $\begin{array}{l}\text { U.S., BENELUX, Denmark, } \\
\text { Ftalle, Gretw, Iculand, I Ialy, } \\
\text { UK, Norway, Portugal, Turkey, } \\
\text { Federal Republic of Germany }\end{array}$ \\
\hline $\begin{array}{l}\text { Organization for Economic Co- } \\
\text { operation and Development } \\
\text { (OECD) }\end{array}$ & 1961 & $\begin{array}{l}\text { Conduct air and water management, early warning sys- } \\
\text { tems for toxic pollution, urban environmental policy. }\end{array}$ & $\begin{array}{l}24 \text { developed countries, including } \\
\text { U.S. }\end{array}$ \\
\hline OECD Nuclear Energy Agency & 1972 & $\begin{array}{l}\text { Conduct health, safety, and standards research to further } \\
\text { uniform legislation. }\end{array}$ & 19 OECD members and Japan \\
\hline $\begin{array}{l}\text { Organization of African Unity } \\
\text { (OAU) }\end{array}$ & 1963 & |Sponsor research on waste treatment, soil quality. & 41 African countries \\
\hline $\begin{array}{l}\text { Regional Cooperation for } \\
\text { Development }\end{array}$ & 1964 & $\begin{array}{l}\text { Develop and protect water resources, sponsor nuclear } \\
\text { research. }\end{array}$ & Iran, Pakistan, Turkey \\
\hline $\begin{array}{l}\text { South Pacific Commission } \\
\text { (SPC) }\end{array}$ & 1947 & $\begin{array}{l}\text { Provide recommendations for protection of reefs, fish, } \\
\text { wildrife, forests, and plants from environmental pollution. }\end{array}$ & $\begin{array}{l}\text { U.S.. UK, France, Western Samoa, } \\
\text { Fiji, New Zealand, Australia }\end{array}$ \\
\hline
\end{tabular}




\begin{tabular}{|c|c|c|c|}
\hline ORGANIZATION & $\begin{array}{l}\text { DATE } \\
\text { EST. }\end{array}$ & $\begin{array}{l}\text { ENERGY-RELATED } \\
\text { ENVIRONMENTAL RESPONSIBILITIES }\end{array}$ & MEMBERSHIP \\
\hline $\begin{array}{l}\text { Association of African } \\
\text { Geological Surveys }\end{array}$ & 1929 & $\begin{array}{l}\text { Encourage research in geological science and related envi- } \\
\text { vironmental problems. }\end{array}$ & $\begin{array}{l}\text { Geological services of all African } \\
\text { governments, public and private } \\
\text { organizations }\end{array}$ \\
\hline The Club of Rome & 1968 & $\begin{array}{l}\text { Seek to identify environmental problems confronting } \\
\text { man on a global basis; sponsor conferences and research. }\end{array}$ & 75 members in 25 countries \\
\hline $\begin{array}{l}\text { Commonwealth Human } \\
\text { Ecology Council }\end{array}$ & 1969 & $\begin{array}{l}\text { Investigate interaction of man, his activities and the envi- } \\
\text { ronment: seek most effective balance between man's } \\
\text { needs and available resources. }\end{array}$ & Individuals and corporate groups \\
\hline $\begin{array}{l}\text { Conference of Non-Govern- } \\
\text { mental Organizations in Consul- } \\
\text { tative Status with the UN } \\
\text { ECOSOC }\end{array}$ & 1950 & $\begin{array}{l}\text { Maintain a committee concerned with issues coming } \\
\text { before the UN Environment Council. }\end{array}$ & $\begin{array}{l}\text { All NGOs enjoying consultative } \\
\text { status with ECOSOC }\end{array}$ \\
\hline $\begin{array}{l}\text { European Atomic Energy } \\
\text { Society (EAES) }\end{array}$ & 1954 & $\begin{array}{l}\text { Seek peaceful applications of nuclear research; consider } \\
\text { environmental, health and safety factors. }\end{array}$ & $\begin{array}{l}\text { National commissions in } 13 \\
\text { countries }\end{array}$ \\
\hline $\begin{array}{l}\text { European Committee for the } \\
\text { Protection of the Population } \\
\text { Against the Hazards of Chronic } \\
\text { Toxicity (EUROTOX) }\end{array}$ & 1957 & Conduct research on atmospheric and water toxicity. & $\begin{array}{l}\text { Members in } 18 \text { European and } 2 \\
\text { non-European countries }\end{array}$ \\
\hline $\begin{array}{l}\text { Friends of the Earth } \\
\text { International }\end{array}$ & 1969 & $\begin{array}{l}\text { Promote international exchange of information (1975 } \\
\text { meeting focused on problems of nuclear energy). }\end{array}$ & 25,000 members, 50 lacal groups \\
\hline The Institute of Ecology (TIE) & 1971 & $\begin{array}{l}\text { Direct and coordinate ecological analyses and research } \\
\text { projects in the Western Hemisphere. Topics have included } \\
\text { coastal zone management, tropical ecology, urban and } \\
\text { marine ecosystems. }\end{array}$ & $\begin{array}{l}\text { Members include } 102 \text { universities } \\
\text { and research institutions }\end{array}$ \\
\hline $\begin{array}{l}\text { International Assembly of Non- } \\
\text { governmental Organizations } \\
\text { Concerned with the Environ- } \\
\text { ment (INASEN) }\end{array}$ & 1973 & $\begin{array}{l}\text { Conduct research on population problems, health, } \\
\text { biology, systems approach to environmental dynamics. }\end{array}$ & $\begin{array}{l}\text { Open to all environmentally con- } \\
\text { cerned NGOs }\end{array}$ \\
\hline $\begin{array}{l}\text { International Association for } \\
\text { Ecology (INTECOL) }\end{array}$ & 1967 & $\begin{array}{l}\text { Promote the science and practice of ecology by providing } \\
\text { opportunities for communications among ecologists } \\
\text { through symposia and publications. }\end{array}$ & Individuals, affiliated societies \\
\hline $\begin{array}{l}\text { International Association of } \\
\text { Meteorology and Atmospheric } \\
\text { Physics (IAMAP) }\end{array}$ & 1919 & $\begin{array}{l}\text { Conduct research on atmospheric ozone protection, air } \\
\text { pollution. }\end{array}$ & Individuals and organizations \\
\hline $\begin{array}{l}\text { International Association } \\
\text { of Theoretical and Applied } \\
\text { Limology (IAL) }\end{array}$ & 1922 & Study geographic and biological aspects of fresh water. & 2300 members in 58 countries \\
\hline $\begin{array}{l}\text { International Association on } \\
\text { Water Pollution }\end{array}$ & 1962 & Study international water pollution problems. & $\begin{array}{l}820 \text { associate and individual mem- } \\
\text { bers in } 30 \text { coun tries }\end{array}$ \\
\hline $\begin{array}{l}\text { International Council of } \\
\text { Environmental Law }\end{array}$ & 1969 & $\begin{array}{l}\text { Promote the exchange of information and contacts be- } \\
\text { tween persons active in environmental policy and law. }\end{array}$ & $\begin{array}{l}\text { Corporate and individual mem- } \\
\text { bers in } 24 \text { countries }\end{array}$ \\
\hline $\begin{array}{l}\text { Internatlond Council of } \\
\text { Scientific Unions (ICSU) }\end{array}$ & 1919 & $\begin{array}{l}\text { Conordinate research among member groups, study } \\
\text { solar-terrestrial physics, marine and fresh water quality, } \\
\text { impacts of technological development on the } \\
\text { environment. }\end{array}$ & $\begin{array}{l}\text { Scientific unions, national re- } \\
\text { search councils and ralated scien. } \\
\text { tific and governmental } \\
\text { institutions }\end{array}$ \\
\hline $\begin{array}{l}\text { International Federation for } \\
\text { Medical and Biological } \\
\text { Engineering (FMBE) }\end{array}$ & 1959 & $\begin{array}{l}\text { Encourage research on environmental health problems, } \\
\text { particularly in developing countries; disseminate scien- } \\
\text { tific information. }\end{array}$ & $\begin{array}{l}\text { Affiliated organizations in } 18 \\
\text { countries }\end{array}$ \\
\hline $\begin{array}{l}\text { International Foundation } \\
\text { for Science (IFS) }\end{array}$ & 1972 & $\begin{array}{l}\text { Promote research in technology and natural sciences in } \\
\text { developing countries; provide financial aid to scientists } \\
\text { for research projects beneficial to the Third World. }\end{array}$ & $\begin{array}{l}\text { Academies and } 21 \text { representative } \\
\text { groups from } 19 \text { countries }\end{array}$ \\
\hline $\begin{array}{l}\text { International Radiation Protec- } \\
\text { tion Association (IRPA) }\end{array}$ & 1966 & $\begin{array}{l}\text { Exchange information among scientists engaged in } \\
\text { radiation protection work. }\end{array}$ & 7.000 individuals in 55 countries \\
\hline $\begin{array}{l}\text { International Union for Geod- } \\
\text { esy and Geophysics (IUGG) }\end{array}$ & 1919 & $\begin{array}{l}\text { Promote study of all problems concerning the configura- . } \\
\text { tion of the earth and the physics of the globe, oceans, } \\
\text { and atmosphere. }\end{array}$ & $\begin{array}{l}7 \text { constituent international } \\
\text { organizations }\end{array}$ \\
\hline $\begin{array}{l}\text { International Union for Conser- } \\
\text { vation of Nature and Natural } \\
\text { Resources (IUCN) }\end{array}$ & 1948 & $\begin{array}{l}\text { Promote and support projects to ensure conservation of } \\
\text { nature and natural resources; review and assess world en- } \\
\text { vironmental problems; advise governments and private } \\
\text { groups. }\end{array}$ & $\begin{array}{l}\text { National governments, govern- } \\
\text { ment agencies, private organiza- } \\
\text { tions, and international groups in } \\
93 \text { countries }\end{array}$ \\
\hline $\begin{array}{l}\text { International Union of Pure and } \\
\text { Applied Chemistry (IUPC) }\end{array}$ & 1919 & $\begin{array}{l}\text { Conduct research on toxicology, industrial hygiene, } \\
\text { pesticides, water quality, waste management. }\end{array}$ & $\begin{array}{l}\text { National organizations in } 43 \\
\text { countries }\end{array}$ \\
\hline $\begin{array}{l}\text { International Union of Pure and } \\
\text { Applied Physics (IUPAP) }\end{array}$ & 1922 & $\begin{array}{l}\text { Study noise pollution and other environmental } \\
\text { problems. }\end{array}$ & $\begin{array}{l}\text { National committees in } 36 \\
\text { countries }\end{array}$ \\
\hline $\begin{array}{l}\text { World Environment and } \\
\text { Resources Council }\end{array}$ & 1973 & $\begin{array}{l}\text { Promote the sciences, whether theoretical or applied, of } \\
\text { environmental improvernent and resource utilization in } \\
\text { all technologies. }\end{array}$ & National councils in 13 countries \\
\hline
\end{tabular}

\section{EXHIBIT 14}

SELECTED INTERNATIONAL NONGOVERNMENTAL ORGANIZATIONS ENERGY/ENVIRONMENTAL FUNCTIONS 
Geodesy and Geophysics. Education in environmental issues is a major interest of IUCN's Commission on Education. The International Commission on Radiation Units and Measurements works toward the development of internationally acceptable standards for radioactivity. The International Council of Environmental Law and the IUCN Environmental Law Center are the leading information clearinghouses on international and national environmental law, policy, and administration. 
SECTION XI

CONCLUSION

In the interest of efficiency, organizations involved with energy-related EH\&S issues are careful not to invest resources on subjects and activities which have been covered adequately by others. To avoid duplication of effort, almost every group participates in informal or structured coordination in planning and program imple-: mentation. Exhibit 15 illustrates how this process often proceeds.

The Federal Interagency Energy/Environment Research and Development Program offers perhaps the best example of how governmental organizations interact on EH\&S matters. It was established by the Environmental Protection Agency (EPA) to integrate environmental and energy research and development. The Program includes, but is not limited to the following Federal agencies: The Departments of Agriculture; Commerce; Defense; Energy; Health, Education and Welfare; Housing and Urban Development; Interior; Labor; and Transportation; the Environmental Protection Agency (EPA); the National Science Foundation; the Nuclear Regulatory Commission; and the Tennessee Valley Authority.

A second example of Federal interagency cooperation is the "Inventory of Federal Energy-Related Environmental and Safety Research," published annually by DOE. The Inventory compiles data on Federally-funded research for each fiscal year, and is analyzed by 


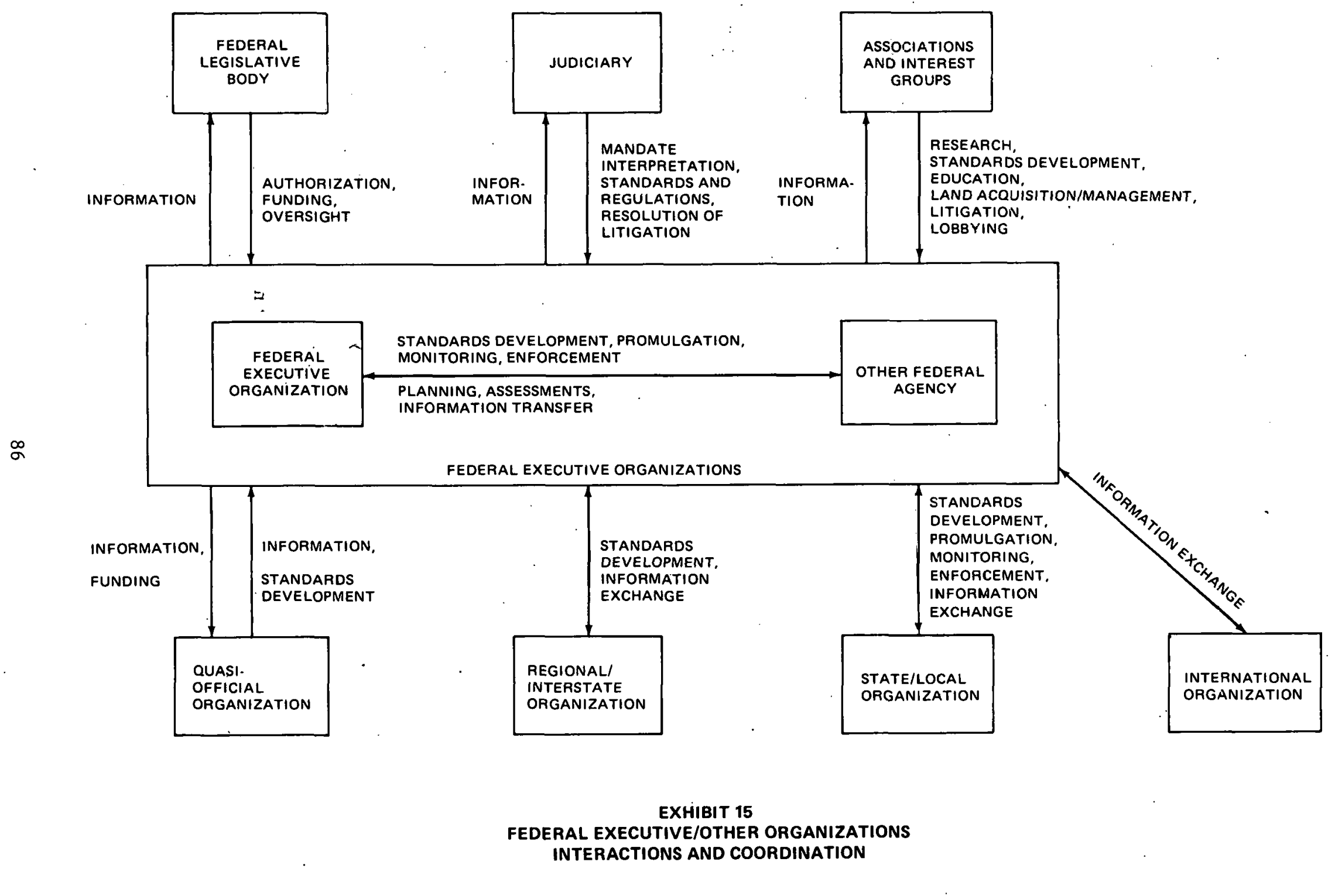


DOE; in conjunction with other agencies, to identify gaps and redumdanciea in Federal research programs. This analysis is extremely useful for R\&D planning.

The Memorandum of Understanding (MOU) is yet another formal device by which Federal agencies interact. The MOU may be addressed to a specific topic, or may be an agreement to participate in an interagency group. In addition to the formal methods cited above, informal agreements are often established between two or more Federal organizations.

Non-Federal organizations coordinate EH\&S efforts via a number of mechanisms, some of which allow participation by Federal agencies. Federal/state partnerships commonly take the form of regional commissions designed to promote orderly economic growth in specific multistate areas. Executive orders or interstate compacts have established other organizations to conduct planning and assessment activities for regional water policies. The Water Resources Council consolidates individual regional evaluations into a nationwide assessment. Other non-Federal mechanisms involve sponsorship of conferences or symposia on energy and environmental topics, annual meetings, and publication of reports and scientific and professional journals.

One innovative approach to program coordination was developed by the governors of Colorado, Montana, New Mexico, Utah, and Wyoming. To address their common problems, such as water shortages, ecosystem 
imbalances, and exploitation of fossil fuel reserves--the governors established a private, non-profit corporation, the Federation of Rocky Mountain States. A sub-group within the Federation addresses regional energy development and environmental protection. The governors of Arizona, Nebraska, Nevada, North Dakota, and South Dakota joined with Federation members to form the action-oriented Western Governors' Regional Energy Policy Office.

It is vital that the foregoing mechanisms for energy/environmental coordination be continually strengthened and improved. Clearly, the problems of anticipating and mitigating energy-related environmental, health, and safety impacts can only grow more complex. By consolidating available information on the organizations which need to maintain continual and close contact with one another, this directory provides another mechanism for coordination. 
1. Battelle Columbus Laboratories. Energy Information Resources. American Society for Information Science, Washington, D.C. 1975.

2. Burke, John G. and Jill S. Reddig. Guide to Ecology Information and Organizations. H. W. Wilson Co., New York, N.Y. 1976.

3. Cohen, Felix S. Handbook of Federal Indian Law. Government Printing office, Washington, D.C. 1942.

4. Congressional Staff Directory, 1978 Edition. Mount Vernon, Va.*

5. Council of Energy Resource Tribes. Unpublished descriptive material. Washington, D.C.

6. Energy Directory Update. Environment Information Center, Inc., New York, N.Y.*

7. National Wildlife Federation. Conservation Directory, 22nd Edition. Washington, D.C. 1977.*

8. Onyx Group, Inc. Environment U.S.A.: A Guide to Agencies, People, and Resources. R.R. Bowker Co., New York, N.Y. 1974.

9. Pair, Mary W., Ed. Encyclopedia of Associations, 12th Edition. Gale Research Co., Detroit, Mich. 1978.*

10. Palmer, Archie M., Ed. Research Centers Directory, 5th Edition. Gale Research Co., Detroit, Mich. 1975.*

11. Ross, H. John, Ed. The Energy Activists Directory. Office Research Institute, Miami, Fla. 1975.*

12. Sierra Club. World Directory of Environmental Organizations, 2nd Edition. Thaddeus C. Trzyna and Eugene V. Coan, Eds. Public Affairs Clearinghouse, Claremont, Calif. 1976.*

13. Sullivan, Linda E. and Anthony T. Kruzas, Eds. Encyclopedia of Governmental Advisory Organizations, 2nd Edition. Gale Research Co., Detroit, Mich. 1975.*

14. Sullivan, Linda E. and Anthony T. Kruzas, Eds. New Governmental Advisory Organizations. Gale Research Co., Detroit Mich.*

*Regularly updated. 
READING LIST (Continued)

15. Tetra Tech, Inc. Energy Fact Book-1977. Arlington, Va. 1977. TT-A-642-77-306.

16. Thibeau, Charles E., Ed. NFEC Directory of Environmental Information Sources, 2nd Edition. National Foundation for Environmental Control, Inc., Boston, Mass. 1972.

17. United Nations, Economic and Social Council. Committee on Natural Resources: Report on the Fifth Session. 9-20 May 1977. E/6004..E/C. 7/76. Supplement No. 2A.

18. United Nations. United Nation's Environment Programme: Report of the Governing Council on the Work of Its Fifth Session. 9-25 May 1977. General Assembly. Official Records: Thirty-second Session. Supplement No. 25 (A/32/25).

19. United Nations. Report of the United Nations Conference on the Human Environment. Stockholm, Sweden. 5-16 June 1972. $\overline{\mathrm{A} / \mathrm{CONF} .48 / 14 / \mathrm{Rev} .1}$.

20. U.S. Congress. Official Congressional Directory. Government Printing Office, Washington, D.C.*

21. U.S. Council on Environmental Quality. Environmental Quality: The Eighth Annual Report of the Council on Environmental Quality. Washington, D.C. December 1977.*

22. U.S. Council on Environmental Quality. The Federal Environmental Monitoring Directory. U.S. Government Printing Office, Washington, D.C. May 1973.

23. U.S. Department of Energy, Division of Environmental Control Activities. Environmental Control Technology Activities of the Department of Energy in FY 1977. Washington, D.C. November 1977. DOE/EV-0030.*

24. U.S. Department of Energy. Fact Book: Organization and Functions. Washington, D.C. September 1977.

25. U.S. Department of Interior, Bureau of Indian Affairs. The American Indians: Answers to 101 Questions. Government Printing Office, Washington, D.C. June 1974. 0-551-103

*Regularly updated. 
26. U.S. Department of Interior, Bureau of Indian Affairs. Federal Indian Policies - From the Colonial Period through the Early 1970 's. Government Printing Office, Washington, D.C. 1975. S/N 2402-00042.

27. U.S. Energy Research and Development Administration. A National Plan for Energy Research, Development and Demonstration. Government Printing office, Washington, D.C. June 1977. ERDA 77-1.

28. U.S. Environmental Protection Agency, Office of Research and Development, Office of Energy, Minerals, and Industry. Interagency Energy/Environment R\&D Program, Energy/Environment Decision Series. Washington, D.C. March 1977. EPA-600/7-77-007.

29. U.S. Federal Energy Administration, National Energy Information Center. Directory of State Government Energy-Related Agencies. Washington, D.C. September 1975. FEA/C-75/515.

30. U.S. General Accounting Office, Office of Program Analysis. Federal Information Sources and Systems: A Directory for the Congress, Congressional Sourcebook Series. Government Printing Office, Washington, D.C. 1976. OPA-76-23.

31. U.S. General Accounting Office, Office of Program Analysis. Federal Program Evaluations: A Directory for the Congress, Congressional Sourcebook Series. Government Printing Office, Washington, D.C. 1976. PAD-77-5.

32. U.S. General Accounting Office, Office of Program Analysis. Recurring Reports to the Congress: A Directory. Congressional Sourcebook Series. Government Printing Office, Washington, D.C. 1976. OPA-76-21.

33. U.S. General Services Administration, Office of the Federal Register. U.S. Government Manual 1977/78. Government Printing office, Washington, D.C. GPO-022-003-00924-8.*

34. U.S. Library of Congress, National Referral Center. A Directory of Information Resources in the United States: Biological Sciences. Washington, D.C. 1972.

*Regularly updated. 
35. U.S. Senate, Committee on Governmental Affairs, Subcommittee on Reports, Accounting and Management. Federal Advisory Committees. Government Printing Office, Washington, D.C. September 1977.*

36. Water Resources Council. Coordination Directory for Planning Studies and Reports. Washington, D.C. December 1973.

37. World Environmental Directory, 3rd Edition, Business Publishers, Inc., Silver Spring, Md. 1978.*

38. Yearbook of International Organizations, $16 \mathrm{th}$ Edition. Union of International Associations, Brussels, Belgium. 1977.*

*Regularly updated. 
